\title{
Natura 2000 erdei élőhelytípusok szerkezet és funkció monitorozási módszere a Pannon életföldrajzi régióban
}

\author{
Horváth Ferenc ${ }^{1}$, Molnár Csaba ${ }^{2}$, Ortmann-né Ajkai Adrienne ${ }^{3}$, \\ Csicsek Gábor ${ }^{4}$, Szabó Gábor ${ }^{1}, Z^{2}$ mmermann Zita ${ }^{1}$, Lukács Márió ${ }^{1}$ \\ és Bölöni János ${ }^{1}$ \\ ${ }^{1}$ MTA Ökológiai Kutatóközpont, Ökológiai és Botanikai Intézet, \\ 2163 Vácrátót, Alkotmány u. 2-4. \\ ${ }^{2} 3728$ Gömörszölös, Kassai u. 34. \\ ${ }^{3}$ Pécsi Tudományegyetem, Ökológiai és Hidrobiológai Tanszék, \\ 7624 Pécs, Ifjúság útja 6. \\ ${ }^{4}$ Pécsi Tudományegyetem, Biológiai és Sportbiológiai Doktori Iskola, \\ 7624 Pécs, Ifjúság útja 6. \\ e-mail:horvath.ferenc@okologia.mta.hu
}

\begin{abstract}
Összefoglaló: Az élőhelyvédelmi irányelv a még megmaradt természetes élőhelyek kedvező természetvédelmi helyzetének fenntartását, állapotuk javítását és a Natura 2000 élőhelyek állapotának ellenőrző monitorozását írja elö. A Pannon életföldrajzi régió erdőire kidolgoztuk a szerkezet és funkció monitorozás 2008-ban javasolt módszerének egyszerübb, hatékonyabb és továbbfejlesztett változatát, hogy a statisztikai értékeléshez szükséges elegendően nagy, reprezentatív mintaszámot könnyebben el lehessen érni. A módszertant összehangoltuk az erdőrezervátum-kutatás hosszú távú vizsgálati módszereivel, hogy azok eredményei referenciaként összehasonlíthatók legyenek. A természetvédelem 2014 óta alkalmazza ezt a felmérést az 1 millió hektárt meghaladó természetes, természetszerủ vagy származék besorolású erdők állapotának követésére. Részletesen bemutatjuk a továbbfejlesztett módszert, annak munkafolyamatát és adatlapjait, továbbá javaslatot teszünk a korábbi országos mintavételi terv módosítására.
\end{abstract}

Kulcsszavak: élőhelyvédelmi irányelv, erdőtermészetesség, természetvédelmi monitorozás, kedvező természetvédelmi helyzet, országjelentés, TERMERD

\section{Bevezetés}

Az EU élőhelyvédelmi irányelve (92/43/EGK) kötelezi a tagállamokat az irányelv 1. mellékletében szereplő és a Natura 2000 területek kijelölésének alapjául szolgáló Natura 2000 élőhelyek kedvező természetvédelmi helyzetének fenntartására és állapotuk javítására, továbbá azok állapotának monitorozására és a szükséges 
kutatások ösztönzésére (Evans \& Arvela 2012). Hat évente országjelentésekben kell beszámolni a Natura 2000 élőhelyek és fajok természetvédelmi helyzetéről, amelynek tartalmaznia kell a kiterjedési terület (distribution area) és elterjedési terület (range area) térképét egy 10x10 km-es földrajzi háló szerint, valamint élőhelyek esetében - a pontos kiterjedési adatokat és azok változásának trendjét. Be kell számolni az élőhelyek természetvédelmi szempontú minőségéről, amelyet az élöhelyek ún. „szerkezet és funkció” állapota és a ,, tipikus fajok” helyzete alapján kell értékelni, továbbá a főbb veszélyeztető tényezőkről és a várható jövőbeni kilátásokról. Ezután az élőhelyek (és fajok) természetvédelmi helyzetének átfogó értékelése szükséges, végül a meghozott természetvédelmi intézkedések bemutatása (Evans \& Arvela 2012). Legutóbb a 2007-2012-ig terjedő időszakról készültek országjelentések. A következő jelentési periódus pedig 2013-2018-ra fog vonatkozni (EC ENV). Elvárás, hogy az országjelentések és a trendek bemutatása teljes körü felvételezések, vagy mintavételezésen alapuló statisztikai módszerekkel, modellezéssel alátámasztott becslések alapján készüljenek. Az irányelvek a természetvédelmi állapot nyomon követését határozzák meg, de ehhez nem rendelnek egységes monitorozó módszertant. A különböző életföldrajzi régiókhoz tartozó, eltérő környezeti és társadalmi adottságú, nem utolsó sorban pedig eltérô természetvédelmi biológiai kutatási és monitorozási tradíciókkal bíró tagállamok ennek megfelelően eltérő módszereket fejlesztettek ki és alkalmaznak (pl. Cantarello \& Newton 2008, Hernando et al. 2010, Velázquez et al. 2010, Kutnar et al. 2011, Tejera et al. 2012, Louette et al. 2015, Angelini et al. 2016).

Magyarországon az erdők természetvédelmi célú szerkezet és funkció monitorozására Bölöni (2008) javasolt egy intenzív és egy extenzív módszertani változatot, a TERMERD projekt (Magyarországi erdők természetességét felmérő és értékelő program) koncepciójának és tanulságainak felhasználásával (Bartha et al. 1998, 2003, 2006, 2007). Az időközben felmerült módszertani kérdések, a kiemelt botanikai szaktudást igénylő követelmények, valamint kapacitás- és forráshiány miatt a széleskörü terepi alkalmazás elmaradt. Éppen ezért felmerült a módszertan egyszerüsítésének és továbbfejlesztésének igénye. Szerzők az extenzív módszertan továbbfejlesztésére tettek javaslatot, amelynek fó célkitüzései:

- a módszer egyszerüsítése és hatékonyabbá tétele, hogy a reprezentatív mintavételhez szükséges, nagyobb mintaszámot el lehessen érni és a monitorozás intenzitását hosszú távon is fenn lehessen tartani, hogy a felmérök számát szélesíteni lehessen;

- a mintavételi módszer összehangolása az erdőrezervátum-kutatás módszereivel és eredményeivel, hogy azok a Natura 2000 erdőmonitorozás természetes referenciájaként közvetlenül is hasznosulhassanak;

- közvetlen adatgyüjtés az országjelentésekhez megkövetelt információk körében (ható és várható veszélyeztető tényezők; tipikus fajok értékelése). 
A korábbi javaslat és a monitorozás országos mintavételi terve (Horváth et al. 2008) nem veszi figyelembe a vágásos erdőgazdálkodás által régóta kialakított újulat - fiatalos - középkorú erdő - öreg erdő állapotok térbeli mintázatát és időbeli sorozatait, ciklusait. Pedig a döntő mértékben vágásos gazdálkodás múltbeli és jelenkori gyakorlata hosszú távra meghatározza az ország természetközeli erdőinek állapotát és természetességét. A vágásos erdőgazdálkodásban az öregebb állományok szerkezete változatosabb, ökológiai funkciói teljesebbek, állapota általában természetesebb. A vágásos erdőgazdálkodást elsősorban a zonális, kiterjedtebb, ill. gazdasági szempontból jelentősebb erdei élőhelytípusokban alkalmazzák, ahol ezt is figyelembe kell venni az országos szintű reprezentativitás elérése érdekében. Ugyan vannak már örökerdő koncepcióval (is) gazdálkodó erdészetek, de az így kezelt állományok kiterjedése országos szinten még alárendelt. Ezért további célkitüzésünk volt:

- az országos mintavételi terv jobb összehangolása és módosítása az erdőgazdálkodásunkban még hosszú ideig meghatározó vágásos üzemmód ciklikusságával.

\section{Módszerek}

\section{A felmérés módszertani fejlesztése}

A módszertani fejlesztés Magyarország, ill. a Pannon életföldrajzi régió Natura 2000 erdei élőhelytípusainak szerkezet és funkció monitorozására vonatkozik. A típusok részletes leírását Bölöni et al. (2011) és Molnár (2014) adja. Felsorolásuk a Natura 2000 élőhelykódok és angol elnevezésük feltüntetésével: mészkerülő bükkösök (9110 - Luzulo-Fagetum beech forests); szubmontán és montán bükkösök (9130 - Asperulo-Fagetum beech forests); sziklai bükkösök, sziklai hárserdők és hársas-berkenyés sziklaerdők (9150 - Medio-European limestone beech forests of the Cephalanthero-Fagion); törmeléklejtö- és szurdokerdők (9180* - TilioAcerion forests of slopes, screes and ravines); puhafás ligeterdők, éger- és kőrisligetek, ill. láperdők (91E0* - Alluvial forests with Alnus glutinosa and Fraxinus excelsior); keményfás ligeterdők (91F0 - Riparian mixed forests of Quercus robur, Ulmus laevis and minor, Fraxinus excelsior or angustifolia along the great rivers); pannon gyertyános-tölgyesek (91G0* - Pannonic woods with Quercus petraea and Carpinus betulus); pannon molyhos tölgyesek (91H0* - Pannonian woods with Quercus pubescens); euro-szibériai (kontinentális) erdőssztyepp tölgyesek (91I0* - Euro-Siberian steppic woods with Quercus spp.); illír bükkösök (91K0 Illyrian Fagus sylvatica forests); illír gyertyános-tölgyesek (91L0 - Illyrian oak- 
hornbeam forests); pannon cseres-tölgyesek (91M0 - Pannonian-Balkanic turkey oak-sessile oak forests) és pannon homoki borókás-nyárasok (91N0* - Pannonic inland sand dune thicket). Rendkívüli ritkaságuk és kis kiterjedésük miatt ezt a mintavételes monitorozó módszertant nem alkalmazzuk a nyíres és fenyves láperdők (91D0*_ Bog woodland) kategóriára, hiszen a természetvédelem minden állományának állapotát figyelemmel követi.

A módszertani továbbfejlesztést megalapozó első értekezletet az MTA Ökológiai Kutatóközpont Ökológiai és Botanikai Intézetében rendeztük 2013 elején. A felmérés-módszertani részletek és adatlapok kidolgozása, tesztelése és a szakértői megbeszélések 2014 nyaráig folytak, egyeztetve az FM Természetmegőrzési Főosztály és a nemzeti park igazgatóságok munkatársaival. Közben regionális tréningeket tartottunk Hetvehelyen, Vácrátóton és Gömörszőlősön, míg a monitorozandó, ún 'tipikus fajok' élőhely specifikus listáit felkért botanikus szakértők bevonásával állítottuk össze (amelynek részleteit külön cikkben publikáljuk).

A módszert úgy fejlesztettük tovább, hogy annak alapját Bölöni (2008) „erdők extenzív felmérése” módszertani leírás adta. Az ún. „intenzív felmérés” cönológiai-mintavételes megközelítésü, nagyon munkaigényes és magas szaktudást feltételez. Ezért a lágyszárú és moha fajok gyakoriságának becslésével bővített almintakörös felmérés módszerét nem is vettük számításba. Az „,extenzív felmérés" és a továbbfejlesztett (extenzív felmérés) módszertana közötti főbb különbségeket, fejlesztéseket az 1. táblázatban foglaltuk össze, az azonosságokat és kisebb eltéréseket nem említjük. A továbbfejlesztett módszertan koncepcionálisan is más az i) egységesen 1 hektáros mintavételi terület, 4 részminta alkalmazásában; ii) a fafajok vastagságának és dominanciájának fafajsorok szerinti leképezésében; iii) abban, hogy a fajok csoportosítása nem a terepen történik, hanem az értékelés során (terepen a fajokat csak azonosítani kell); iv) a holtfa viszonyok leírásában csak a két legfontosabb indikátort - a vastag álló, ill. csonk és a vastag fekvő holtfa hektáronkénti számát - alkalmazzuk; v) a tipikus és özönfajok élőhelyenként előre meghatározott listájának alkalmazásában, ahol a „nem fordul elő” státuszt is rögzíteni kell; vi) a részletesebben kidolgozott adatlapban és értékelési módszertanban (Szegleti et al. 2017).

A módszertan részleteit továbbá úgy alakítottuk át, hogy a mintavételi területek részmintáinak kijelölése és létesítése könnyen igazítható legyen az erdőrezervátum magterületeken alkalmazott mintavételi pontok hálózatához (ERDÖ+h+á $+1+o ́)$ és a felmérés összhangban legyen az erdőrezervátum-kutatás hosszú távú faállomány-szerkezeti (Horváth et al. 2011, Horváth 2012), újulati és cserjeszint (Horváth 2011), valamint az aljnövényzet (Ódor et al. 2009) alapfelmérési és monitorozási módszereivel és eredményeivel. Az erdőrezervátum-kutatás felmérések egy (kiválasztott) részét így transzformálni lehet Natura 2000 élőhely szerkezet és 
1. táblázat. Fő különbségek, ill. fejlesztések a korábbi „extenzív felmérés” módszertanához képest.

\begin{tabular}{|c|c|c|c|}
\hline $\begin{array}{l}\text { Módszertani tulaj- } \\
\text { donság }\end{array}$ & „Extenzív felmérés”, 2008 & $\begin{array}{l}\text { Továbbfejlesztett módszer- } \\
\text { tan, } 2014\end{array}$ & A fejlesztés eredménye \\
\hline $\begin{array}{l}\text { mintavételi terület } \\
\text { mérete }\end{array}$ & változó: $(0,1-) 0,5-2(-3)$ ha & $\begin{array}{l}\text { egységesen azonos: } 1 \text { ha } \\
\text { (négyzetes vagy hosszú- } \\
\text { kás/téglalap alakban) }\end{array}$ & $\begin{array}{l}\text { megfelel a statisztikai } \\
\text { mintavétel } \\
\text { i) azonos körülmények, } \\
\text { ii) torzítatlan adatok } \\
\text { követelményeinek }\end{array}$ \\
\hline $\begin{array}{l}\text { részminták száma } \\
\text { és elrendezése }\end{array}$ & $\begin{array}{l}\text { változó: } 2-6 \text { db, elrendezé- } \\
\text { sük szabályos hálóban törté- } \\
\text { nik, amelyet a vázlatrajzon } \\
\text { kell feltüntetni }\end{array}$ & $\begin{array}{l}\text { egységesen azonos: } 4 \mathrm{db} \text {, } \\
\text { elrendezésük } 50 \times 50 \mathrm{~m}- \\
\text { es hálóban, vagy vonal } \\
\text { mentén történik (GPS-szel } \\
\text { bemérve) }\end{array}$ & $\begin{array}{l}\text { megfelel a statisztikai } \\
\text { mintavétel } \\
\text { i) azonos körülmények, } \\
\text { ii) torzítatlan adatok } \\
\text { követelményeinek }\end{array}$ \\
\hline $\begin{array}{l}\text { mintaterület kije- } \\
\text { lölése }\end{array}$ & $\begin{array}{l}\text { a terület sarokpontjait kell } \\
\text { megjelölni és a koordinátákat } \\
\text { bemérni GPS-szel }\end{array}$ & $\begin{array}{l}\text { a } 4 \text { részminta középpontját } \\
\text { kell megjelölni és bemérni } \\
\text { GPS-szel, a mintaterület } \\
\text { határát a vázlatrajzon } \\
\text { tüntetjük fel }\end{array}$ & $\begin{array}{l}\text { újrafelméréskor a rész- } \\
\text { minták visszatalálása } \\
\text { pontosabb és gyorsabb; } \\
\text { az } 1 \text { hektáros állomány } \\
\text { „belülről” nézve jobban } \\
\text { áttekinthető }\end{array}$ \\
\hline felmérési időszak & $\begin{array}{l}\text { meghatározó tavaszi geofiton } \\
\text { aszpektussal rendelkező } \\
\text { élőhelyek esetében }(9130, \\
\text { 9180, 91F0, 91G0, 91K0, } \\
\text { 91L0) május, a többi élő- } \\
\text { helynél június, július, esetleg } \\
\text { augusztus }\end{array}$ & $\begin{array}{l}\text { nyáron, május végétöl } \\
\text { augusztusig, amikor a } \\
\text { 'tipikus fajok' már beazo- } \\
\text { nosíthatók (nincs közöttük } \\
\text { tavaszi geofiton) }\end{array}$ & $\begin{array}{l}\text { a felmérési időszak } \\
\text { hosszabb, az erőforrá- } \\
\text { sok beosztása könnyebb }\end{array}$ \\
\hline $\begin{array}{l}\text { erdőszerkezeti } \\
\text { szintek leképezése }\end{array}$ & $\begin{array}{l}\text { A - lombkorona szint ( } 5 \\
\text { m-nél magasabb fásszárúak); } \\
\text { B - cserjeszint (fásszárúak } \\
0,5 \text { és } 5 \text { m között); } \\
\text { C - gyepszint ( } 0,5 \text { m alatt } \\
\text { lágyszárúak és fásszárúak); } \\
\text { D - újulati szint (fák } 2 \text { m } \\
\text { alatt, B-vel C-vel átfedésben) }\end{array}$ & $\begin{array}{l}\text { A - lombkorona szint ( } 5 \\
\text { cm mellmagassági átmérőt } \\
\text { elérő vagy vastagabb } \\
\text { fásszárúak); } \\
\text { B - cserjeszint ( } 0,5 \text { m-nél } \\
\text { magasabb fásszárúak); } \\
\text { C - gyepszint (azonos } \\
\text { felfogásban) újulati szintet } \\
\text { külön nem írunk le, a } \\
\text { fafajok újulatát az értékelés } \\
\text { során értelmezzük a B és C } \\
\text { szintek felmérési adataiból }\end{array}$ & $\begin{array}{l}\text { kompatibilis az erdő- } \\
\text { rezervátum-kutatás } \\
\text { erdőszerkezeti koncep- } \\
\text { ciójával }\end{array}$ \\
\hline $\begin{array}{l}\text { fafajok méretének } \\
\text { (átmérőjének) } \\
\text { leképezése a rész- } \\
\text { mintákban }\end{array}$ & $\begin{array}{l}\text { a fafajok átlagos átmérőjét } \\
\text { kell megadni cm-ben, folyto- } \\
\text { nos változóként; esetenként } \\
\text { tartomány is megadható, ha } \\
\text { az átmérőeloszlás változatos }\end{array}$ & $\begin{array}{l}\text { fafajsorokat képezünk } \\
\text { (cserjefajokra is), } 5-15 \mathrm{~cm} \text {, } \\
16-30 \mathrm{~cm}, 31-60 \mathrm{~cm} \text { és } \\
>60 \mathrm{~cm} \text { átmérőcsoport } \\
\text { választható; egy-egy fafaj } \\
\text { több fafajsort is képezhet, } \\
\text { ha változatos az átmérő- } \\
\text { eloszlás }\end{array}$ & $\begin{array}{l}\text { fafajsorok alapján } \\
\text { jobban leképezhe- } \\
\text { tő egy változatos } \\
\text { átméröszerkezet; a } \\
\text { megadott átmérőcsoport } \\
\text { tartományok használata } \\
\text { egyértelmübb, objektí- } \\
\text { vebb és könnyebb }\end{array}$ \\
\hline $\begin{array}{l}\text { fafajok dominanci- } \\
\text { ájának leképezése a } \\
\text { részmintákban }\end{array}$ & $\begin{array}{l}\text { „súlyozott darabszámot” kell } \\
\text { képezni (a vastagabb fákat } \\
\text { súlyozottan kell beszámítani) }\end{array}$ & $\begin{array}{l}\text { a fafajsorokhoz ,VAN”, } \\
1-5 \%, 6-25 \%, 26-50 \%, \\
\text { „TÖBB” elegyarány (do- } \\
\text { minancia) kategóriát kell } \\
\text { választani }\end{array}$ & $\begin{array}{l}\text { a megadott elegyarány } \\
\text { tartományok használata } \\
\text { egyértelmübb, objektí- } \\
\text { vebb és könnyebb }\end{array}$ \\
\hline
\end{tabular}


1. táblázat (folytatás). Fő különbségek, ill. fejlesztések a korábbi „extenzív felmérés” módszertanához képest.

\begin{tabular}{|c|c|c|c|}
\hline $\begin{array}{l}\text { Módszertani tulaj- } \\
\text { donság }\end{array}$ & „Extenzív felmérés”, 2008 & $\begin{array}{l}\text { Továbbfejlesztett módszer- } \\
\text { tan, } 2014\end{array}$ & A fejlesztés eredménye \\
\hline $\begin{array}{c}\text { fafajok csoporto- } \\
\text { sítása }\end{array}$ & $\begin{array}{l}\text { adatlapon kell jelezni: } \\
\text { természetes fafajok, inváziós } \\
\text { fafajok, egyéb idegenhonos } \\
\text { fafajok, nemesített őshonos } \\
\text { fafajok, termőhelyidegen, de } \\
\text { öshonos fafajok csoportjai } \\
\text { szerint }\end{array}$ & $\begin{array}{l}\text { a csoportosítást értékelö } \\
\text { algoritmus végzi el a fafaj, } \\
\text { élőhely és a földrajzi hely } \\
\text { figyelembe vétele alapján }\end{array}$ & $\begin{array}{l}\text { egyszerübb, a csoporto- } \\
\text { sítással a terepen nem } \\
\text { kell foglalkozni }\end{array}$ \\
\hline holtfa leképezése & $\begin{array}{l}5 \mathrm{~cm} \text {-es vagy vastagabb } \\
\text { lábon álló holtfák, facsonkok } \\
\text { száma, részmintánként; } 5 \\
\text { cm-es vagy vastagabb fekvő } \\
\text { holtfák borítása }<1 \%, 1-5 \% \\
\text { és }>5 \% \text { kategóriákban; } \\
\text { vastag ( }>30 \mathrm{~cm} \text { ) álló/csonk } \\
\text { és fekvő holtfák száma }\end{array}$ & $\begin{array}{l}\text { csak a vastag }(>30 \mathrm{~cm}) \\
\text { álló/csonk és fekvő holt- } \\
\text { fákat számoljuk a teljes } \\
\text { mintavételi területre }\end{array}$ & $\begin{array}{l}\text { a kevésbé fontos holtfa } \\
\text { indikátorokat elhagytuk }\end{array}$ \\
\hline cserjeszint & $\begin{array}{l}\text { részmintánként az invázi- } \\
\text { ós, idegenhonos és nitrofil } \\
\text { fa- és cserjefajok csoport- } \\
\text { jának arányát kell megadni, } \\
\text { továbbá az őshonos fajlistát } \\
\text { (a tömegességet is jelezve); } \\
\text { a cserjeszint hiányának okát } \\
\text { és nyomát is (ha van) fel kell } \\
\text { tüntetni }\end{array}$ & $\begin{array}{l}\text { részmintánként a B és } \\
\text { C szinteknél adjuk meg } \\
\text { az előforduló fajokat } \\
\text { dominancia kategóriákkal } \\
\text { (,VAN”, 1-5\%,6-25\%, } \\
26-50 \%, \text {,TÖBB”); a } \\
\text { fajcsoportok minősítését az } \\
\text { értékelés során végezzük el }\end{array}$ & $\begin{array}{l}\text { terepen nem kell } \\
\text { külön becsülni, mert } \\
\text { a fafajsoros felmérés } \\
\text { alapján leképezhető; } \\
\text { a cserjeszint hiányá- } \\
\text { nak oka szubjektív; a } \\
\text { cserjeirtás (nyomát) } \\
\text { pedig a veszélyeztető } \\
\text { tényezőknél lehet/kell } \\
\text { megadni }\end{array}$ \\
\hline gyepszint & $\begin{array}{l}\text { teljes mintaterületre: a } \\
\text { fajgazdagság szakértői mi- } \\
\text { nősítése } 5 \text { fokozatú skálán; } \\
\text { a gyepszintben előforduló } \\
\text { tipikus, inváziós és egyéb } \\
\text { fontos fajok felsorolása (az } \\
5 \% \text { borítást meghaladókat } \\
\text { jelezve); a tipikus fajok } \\
\text { listája élőhelyenként külön, } \\
\text { amely fákat, cserjéket és } \\
\text { geofitonokat is tartalmaz } \\
\text { (kitöltési útmutatóban } \\
\text { felsorolva) }\end{array}$ & $\begin{array}{l}\text { teljes mintaterületre: a } \\
\text { tipikus fajok, özönfajok } \\
\text { elöfordulását és domi- } \\
\text { nanciáját (NINCS, VAN, } \\
1-5 \% \text {, TÖBB kategóriák- } \\
\text { ban) előre megadott lista } \\
\text { alapján kötelező megadni, } \\
\text { adatlapon jelezve a ,nem } \\
\text { fordul elő” eseteket is; a } \\
\text { tipikus fajok listáját egy } \\
\text { szakértői csoport állította } \\
\text { össze (külön publikál- } \\
\text { juk); a degradációt jelző } \\
\text { tömeges (5\%-ot meghala- } \\
\text { dó) és az előforduló egyéb } \\
\text { fajokat tetszőlegesen lehet } \\
\text { feljegyezni }\end{array}$ & $\begin{array}{l}\text { az előre megadott } \\
\text { fajlisták ellenőrzé- } \\
\text { se és a dominancia } \\
\text { kategóriák használata } \\
\text { egyértelmübb, objektí- } \\
\text { vebb és könnyebb }\end{array}$ \\
\hline $\begin{array}{l}\text { veszélyeztető } \\
\text { tényezők }\end{array}$ & $\begin{array}{l}\text { szükebb körü felsorolás ( } 24 \\
\text { tényező + EGYÉB és NEM } \\
\text { ÉSZLELT), megfeleltet- } \\
\text { hetők az országjelentéshez } \\
\text { használandó lista tételeivel, } \\
\text { de kevésbé részletes }\end{array}$ & $\begin{array}{l}\text { bővebb körü, adatlapon vá- } \\
\text { lasztható felsorolás (66 té- } \\
\text { nyező + EGYÉB és NEM } \\
\text { ÉSZLELT), közvetlenül az } \\
\text { országjelentésekhez hasz- } \\
\text { nálandó listából válogatott } \\
\text { tényezők }\end{array}$ & aktuálisabb, pontosabb \\
\hline
\end{tabular}


1. táblázat (folytatás). Fő különbségek, ill. fejlesztések a korábbi „extenzív felmérés” módszertanához képest.

\begin{tabular}{|c|c|c|c|}
\hline $\begin{array}{l}\text { Módszertani tulaj- } \\
\text { donság }\end{array}$ & „Extenzív felmérés”, 2008 & $\begin{array}{l}\text { Továbbfejlesztett módszer- } \\
\text { tan, } 2014\end{array}$ & A fejlesztés eredménye \\
\hline adatlapok & $\begin{array}{l}2 \text { adatlapon van integrálva a } \\
\text { mintavételi terület doku- } \\
\text { mentálása és az állomány } \\
\text { felmérése }\end{array}$ & $\begin{array}{l}\text { külön adatlap a minta- } \\
\text { vételi terület kitüzésére, } \\
\text { azonosítására (M.1 adat- } \\
\text { lap); élőhelytípusonként } \\
\text { külön adatlapok az } 1 \text { ha-os } \\
\text { MVT terület jellemzésére } \\
\text { (M.2A) és a részminták } \\
\text { leírására (M.2B-1 ... } \\
\text { M.2B-4) }\end{array}$ & $\begin{array}{l}\text { a felmérés dokumen- } \\
\text { tálását és az adatok } \\
\text { feldolgozását jobban } \\
\text { támogatja }\end{array}$ \\
\hline $\begin{array}{l}\text { a felmérési eredmé- } \\
\text { nyek értékelése }\end{array}$ & $\begin{array}{l}\text { az adatlapok kiértékelési } \\
\text { útmutatója } 14 \text { szempont } \\
\text { szerint közvetlenül kedvező, } \\
\text { kedvezőtlen és rossz állapo- } \\
\text { tokat ad, további értékelési } \\
\text { szempontok nincsenek } \\
\text { kidolgozva }\end{array}$ & $\begin{array}{l}\text { az értékelési algoritmus } \\
\text { a felmért adatok alapján } \\
41 \text { indikátorváltozót, hét } \\
\mathrm{N} 2 \mathrm{~K} \text { szerkezet és funkció } \\
\text { természetességi szempont } \\
\text { szerint minősít, majd egy } \\
\text { összesített természetessé- } \\
\text { gi mutatót }\left(\mathrm{T}_{\mathrm{N} 2 \mathrm{~K}}\right) \text { számít } \\
\text { (Szegleti et al. 2017) }\end{array}$ & $\begin{array}{l}\text { részletesebben kidolgo- } \\
\text { zott, árnyaltabb értéke- } \\
\text { lésre ad lehetőséget }\end{array}$ \\
\hline $\begin{array}{l}\text { becsült felmérési } \\
\text { idő }\end{array}$ & $\begin{array}{l}\text { a jelentés szerint átlago- } \\
\text { san fél óra, azonban ezt } \\
\text { (véleményünk szerint) csak } \\
\text { nagy gyakorlattal és tudással } \\
\text { rendelkező felmérő képes } \\
\text { teljesíteni, könnyű (átlátható } \\
\text { és bejárható) élőhelytípusok } \\
\text { esetében }\end{array}$ & $\begin{array}{l}3 \text { éves terepi tapasztala- } \\
\text { taink szerint fél és } 1 \text { óra } \\
\text { között, attól függóen, hogy } \\
\text { a monitorozott állomány } \\
\text { mennyire átlátható, } \\
\text { bejárható, cserjés, ill. } \\
\text { szerkezetgazdag és meny- } \\
\text { nyire fajgazdag }\end{array}$ & $\begin{array}{l}\text { a felméréshez szüksé- } \\
\text { ges idő becslése meg- } \\
\text { alapozottabb, az esetek } \\
\text { egy részében rövidebb } \\
\text { (megjegyezzük, hogy } \\
\text { a MVT felkeresése } \\
\text { és megtalálása ennél } \\
\text { általában jóval több időt } \\
\text { igényel) }\end{array}$ \\
\hline
\end{tabular}

funkció monitorozási eredményekké és azokat referencia adatsorként is fel lehet felhasználni.

Az adatlapokon alkalmazott ható és várható veszélyeztető tényezők listájának alapját az European Environment Agency oldalán közzétett végleges referencia lista adta (EEA EIONET, Salafsky et al. 2008), amelyből kiválasztottuk a hazai viszonyokra alkalmazható eseteket. Az adatlapokon ezt az adaptált listát tüntettük fel, amelyen kívül további, egyedi veszélyeztető tényezők is megnevezhetők.

A 2013 és 2014 folyamán kidolgozott módszertant és adatlapokat több, mint 500 mintavételi terület felmérése során alkalmaztuk 2016 végéig.

\section{Korosztályok reprezentativitása}

Az országos mintavételi terv (Horváth et al. 2008) korosztály szempontú értékelése érdekében a korábban javasolt mintavételi helyeket összevetettük az Országos Erdőállomány Adattár (OEA) korcsoportonkénti és természetességi információi- 
val. A monitorozási tervben a javasolt mintavételi helyeket részben a tanulmány szerzői jelölték ki a Magyarország Élőhelyeinek Térképi Adatbázisa (MÉTA adatbázis), ill. az Általános Nemzeti Élőhely-osztályozási Rendszer (ÁNÉR, Molnár et al. 2007, Bölöni et al. 2011) kistáj szintü értékelése és rétegzett random mintavételi elvek alapján (Horváth et al. 2008), részben pedig a nemzeti parkok munkatársai, figyelembe véve az élőhelyek igazgatási területükre eső részarányait és egyéb természetvédelmi szempontokat. A Nemzeti Élelmiszerlánc-biztonsági Hivatal (NÉBIH) Erdészeti Igazgatósága az OEA 2011 decemberi, ellenőrzött és lezárt állapotából a következö lekérdezéseket készítette el megrendelésünkre, amelynek eredményét generalizált térinformatikai fedvények formájában bocsátotta rendelkezésünkre. A 2009. évi erdőtörvényben meghatározott természetességi fokozatok szerint összevont erdőrészletek három csoportját képeztük: a „T” - természetes és természetszerü erdők összevont kategória; az „SZ” - származék erdők; az „I” - idegenhonos, vagyis átmeneti erdők, kultúrerdők és faültetvények összevont csoportját. A korosztályok szerint összevont erdőrészletek öt csoportját: a „ $\leq 20 "$ - húsz éves vagy fiatalabb állományok; a „21-50”- 21 és 50 év kor közötti állományok; az ,51-80” - 51 és 80 év kor közötti állományok; a „>80” - 80 évesnél öregebb állományok csoportjait; végül a „nem besorolható” korú erdőrészleteket. A terv javasolt mintavételi pontjait ArcGIS programmal összemetszettük az OEA természetességi fokozat, ill. korosztály térképi állományaival, amelyekből összesített kimutatásokat, ill. eloszlásokat készítettünk. A térinformatikai átfedés alapján az 1751 tervezett erdős mintavételi helyből az OEA adatbázisa szerint 604 esik természetes vagy természetszerü erdőrészletbe (34\%), 733 ún. származék erdőre (42\%), 132 idegenhonos erdőre (8\%). További 282 esethez $(16 \%)$ viszont nem tudtunk természetességi fokozatot rendelni (mert ezekben nem kaptunk területi átfedést az OEA fedvénnyel). A korosztály viszonyok reprezentativitásának értékelését végül a természetes vagy természetszerü (T) és származék erdők (SZ) csoportjára végeztük el (OEA, 1.022.678 ha), összehasonlítva ugyanezen természetességi fokozatokba eső 1337 tervezett mintavételi hely korcsoport szerinti arányaival, amelynek eredményét oszlopdiagramon mutatjuk be. Ugyanakkor áttekintettük az erdei élőhelytípusok kiterjedését, valamint azok erdőgazdálkodási jelentőségét és összevetettük a 2008-ban javasolt mintaszámok értékeivel. Majd egy új, kis mértékben bővített javaslatot készítettünk a mintavételi helyek számára vonatkozóan a vágásos erdőgazdálkodásból fakadó korosztályok kiegyenlítettebb reprezentálása érdekében. Az országos mintavételre vonatkozó új, módosított javaslatot az alábbi szabályok szerint alakítottuk ki:

a 2008-as javasolt mintaszámokat vettük alapul, mert azok jól tükrözik az élőhelytípusok földrajzi elterjedtségét és regionális, valamint társulástani változatosságát; 
- a kis kiterjedésü, ritka élőhelyek esetében a mintaszámok értékét minimálisan 40-nek vettük (a korábbi javaslatnak megfelelően);

- a javasolt mintaszám alsó határát csökkentettük, ha a becsült összes kiterjedés a korábbihoz képest lényegesen alacsonyabbnak bizonyult Molnár (2014) szerint;

- a gazdasági erdőkre vonatkozóan 1,3 - 1,5 arányban növeltük a korábban tervezett mintaszámot (hogy az alulreprezentált fiatalabb korosztályokban ki lehessen egészíteni a mintavételt).

\section{Eredmények}

\section{A szerkezet és funkció monitorozás továbbfejlesztett felmérési módszere}

\section{Mintavételi terület kijelölése}

A Natura 2000 szerkezet és funkció monitorozás mintavételi területe (MVT) 1 hektáros egység, amelyen egy Natura 2000 erdős élőhelykategória erdőszerkezeti és kezelési szempontból többé-kevésbé egyöntetünek tekinthető állománya található. Az élőhelyfoltok állományai az esetek nagy részében egy hektárnál nagyobb kiterjedésüek, gyakran mozaikolnak szomszédos élőhelyek állományaival. Az MVT-t az elsődleges élőhelyfoltba beágyazottan kell kijelölni (az egyik részminta esetleg lehet eltérő élőhely), lehetőleg úgy, hogy az állomány-, ill. részlethatárokon jelentkező mesterséges szegély vagy fragmentációs hatásoktól - mint amilyen egy vadföld, elektromos távvezeték sávja, széles nyiladék vagy út, erdőrészlet, vágásterület határa - mentes maradjon. A területet tehát erdőrészleten belül, de annak határától legalább 30-50 m távolságra célszerü kijelölni. A ligetes karakterü, ill. erdőssztyepp élőhelyeknél (91E0, 91I0 és 91N0) a mintavételi területre természetüknél fogva esnek vizes, gyepes, cserjés, ill. szegélytársulás állományfoltok, amelyek természetes részei a MVT-nek. Egy MVT lehetőleg négyzet alakú legyen, ideálisan tehát 100 x 100 m-es, amelynek sarkait azonban nem kell kitüzni, mert sokkal inkább a részminták középpontjainak kitüzésére és terepi állandósítására törekszünk (1. ábra). Egy ideálisan elképzelt MVT-ben 50x50 m-es négyzetes kötésben (negyedhektáronként) helyezkednek el a részminták. Ettől az elrendezéstől indokolt esetben (pl. hosszú, keskeny élőhelyfolt) el lehet térni. A MVT kitüzése és terepi állandósítása a részminták középpontjának kitüzésével és koordinátáinak $\pm 5-10 \mathrm{~m}$ pontosságú megadásával és a részminták középpontjai körül álló legközelebbi 6-8 fa tövének festéses megjelölésével történik. A festések a talajhoz közel történjenek, hogy az erdőgazdálkodás jelzéseitől egyértelmü- 


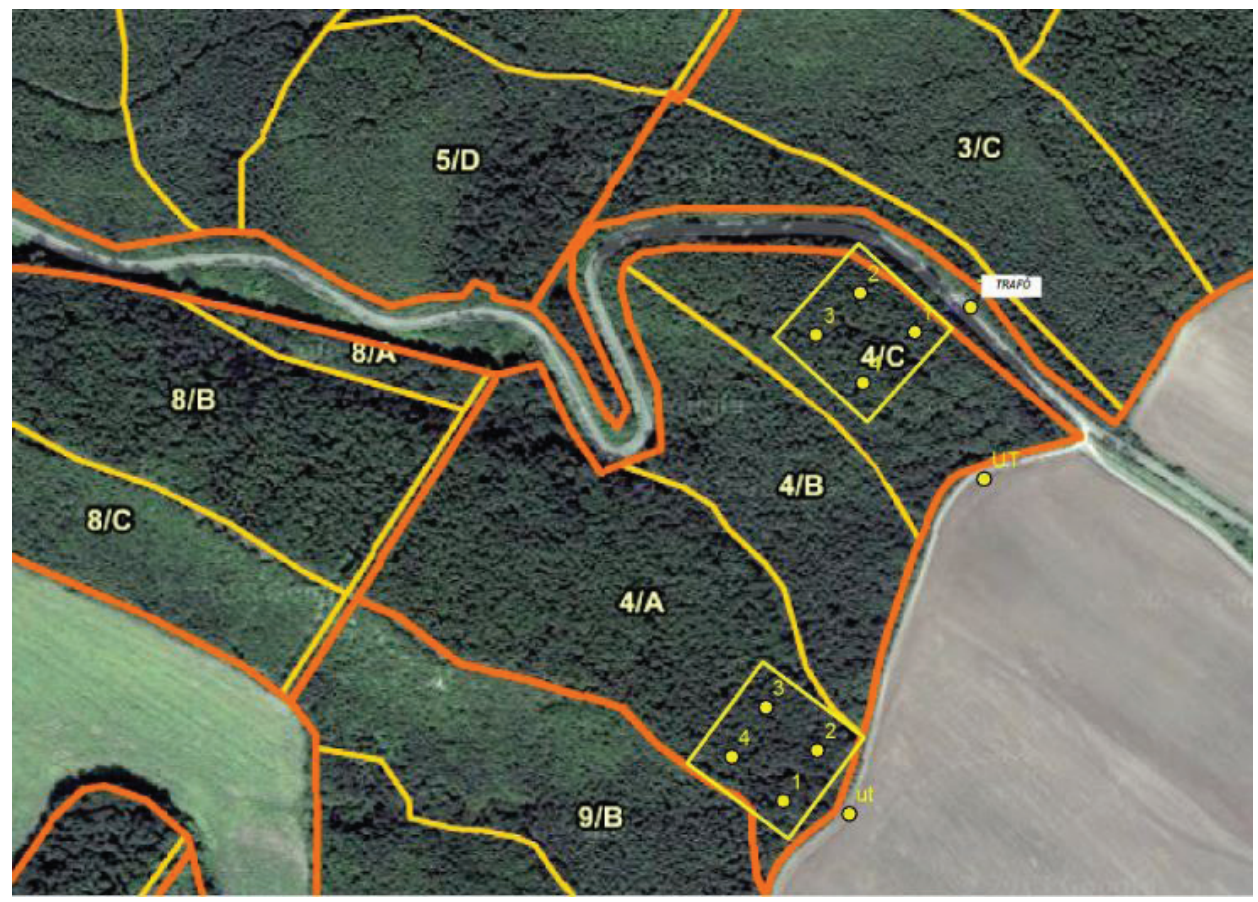

1. ábra. Két mintavételi terület és a részminták elhelyezkedése a Penc 4/A és 4/C részletekben, NÉBIH Erdőtérképen feltüntetve. A terepen a részminták középpontjait jelöljük meg és mérjük be

GPS-szel

en különbözzenek és a jelzések egy gyérítés, vágás után is láthatók maradjanak a megmaradó tuskók tövén. A munkához az erdőrészleteket is feltüntető munkatérkép, ürfelvétel vagy légifotó, továbbá egy kézi GPS, sárga festék és adatlap, fényképezőgép szükséges. Egy mintavételi terület létesítését és a reprezentált Natura 2000 élőhelytípust vázlatrajz elkészítéssel, a koordináták megadásával, szöveges megjegyzésekkel és fotózással az M.1 adatlapon kell dokumentálni (2. ábra).

\section{A felmérés folyamata}

Egy szerkezet és funkció felmérés a már korábban kiválasztott és kitüzött 1 hektáros mintavételi területen történik, amely 4 részmintát foglal magába. Szükségünk van az erdőrészletet, a mintavételi területet és a részminták helyét, helyzetét dokumentáló munkatérképre és/vagy egy táji áttekintést nyújtó aktuális ürfelvételre vagy légifotóra (1. ábra); egy kézi GPS-re; egy fényképezőgépre és a reprezentált élőhelyre vonatkozó adatlapokra. Az adatok terepen jól észlelhető részét közvetlenül a részmintákra, ill. a mintavételi területre vonatkoztatva kell gyüjteni, kisebb részét táji ismeret és/vagy egyéb információ (ürfelvétel, légifotó, élőhelytérkép) 


\section{M.1 Mintavételi terület létesítése adatlap (v1.4)}
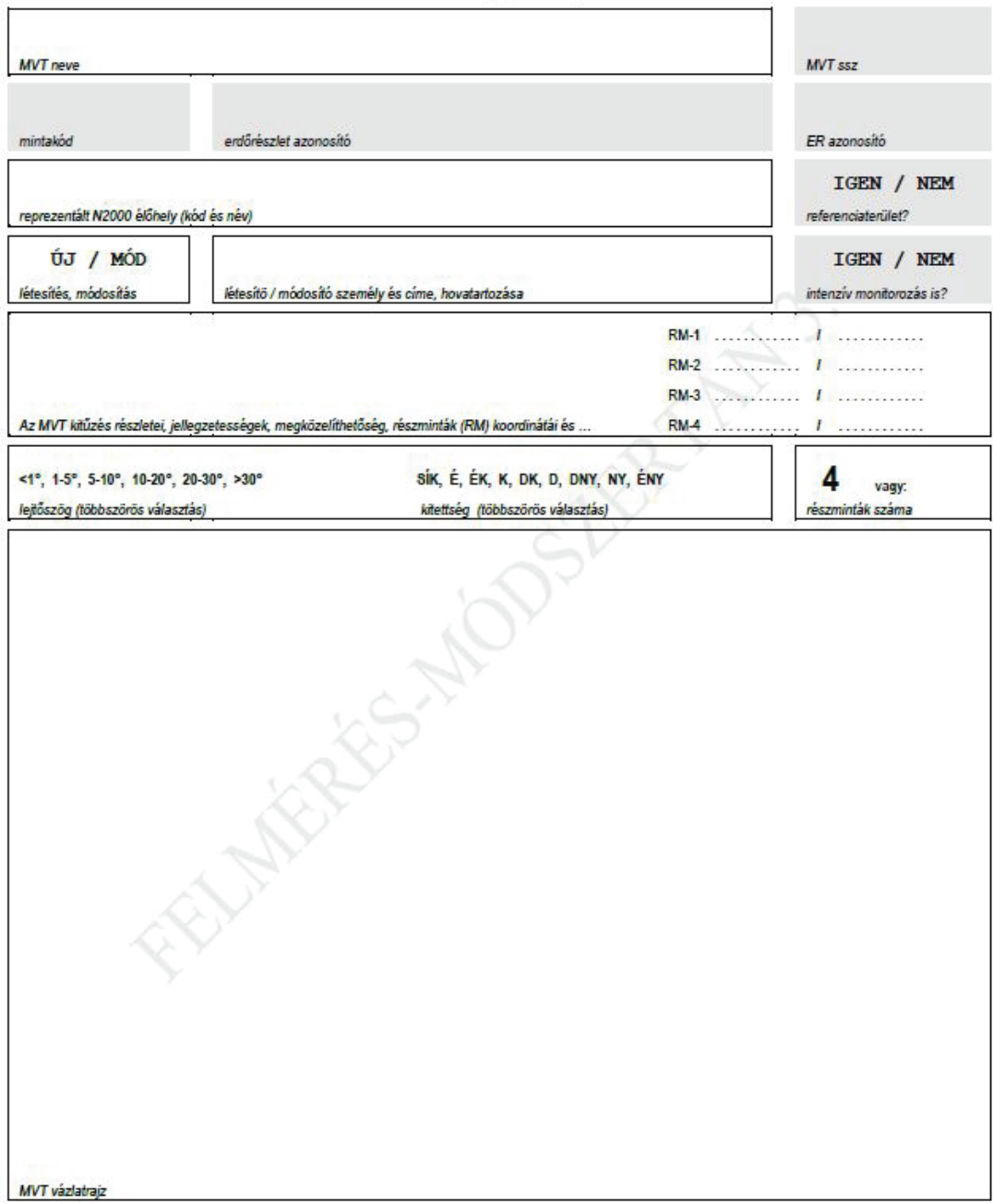

dátum

aláirás

feldolg

2. ábra. Az „M.1” mintavételi terület létesítése adatlap. Az adatlap és a kitöltési útmutató letölthető a http://www.erdorezervatum.hu/N2KMON_modszertan honlapról. 
alapján lehet megadni. A részminták középpontjának térkép és/vagy GPS segítségével történő, majd a terepi jelzések megtalálásával megerősített terepi beazonosítása során átfogó képet kapunk a MVT elhelyezkedéséről és az ott található erdőállományról. A munkát célszerü a részminták bejárásával és felmérésével kezdeni, de már ennek során is gyüjteni érdemes a teljes mintavételi hektárra vonatkozó információkat (pl. a tipikus fajok előfordulását, vagy a vastag fekvő holtfák számolását), majd a végén kitölteni a teljes MVT-re vonatkozó adatlapot, szükség szerint további bejárással pontosítani, kiegészíteni az adatlapokon még tisztázandó kérdéseket.

\section{Az 1 hektáros mintavételi terület erdöállományának felmérése}

A teljes MVT-re vonatkozóan azonosítjuk, ill. ellenőrizzük az erdóállomány Natura 2000 élőhelyi besorolását. A kitöltendő adatlap csomagot ennek megfelelően kell megválasztanunk. Ennek a kijelöléskor meghatározott, ún. „reprezentált élőhely"-lyel azonosnak kell lennie. Mivel az adatlapok tartalma élőhelytől függően eltérő (a tipikus fajok listájában és néhány termőhely ökológiai szempont rögzítésében), ezért a megfelelő adatlap használatára különösen ügyelni kell. Megadjuk továbbá az élőhely természetességét (Németh \& Seregélyes 1989), a fő termőhelyi tulajdonságokat, azok állapotát és a feltételezett változások tendenciáját. Továbbá az idős (vastag) élő fák, a vastag álló holtfák vagy csonkok és a vastag fekvő holtfa törzsek hektáronkénti számát. A táji körülményekre, az elszigeteltségre és az erdőgazdálkodásra vonatkozó információk terepen való kitöltése nem kötelező, ezek más források alapján (pl. üzemterv, üzemtervi térkép, légifotó), utólag is megadhatók. Az adatlapon tematikus csoportosításban felsorolt jelölö listában gyüjtjük az ún. 'ható' (H) és/vagy jövőben 'várható' (V) zavaró és veszélyeztető tényezők körét, amely egyéb (még nem listázott) tényezővel is bővíthető. Ha semmilyen zavarást nem észlelünk, vagy veszélyeztetésre nem számítunk, akkor ezt külön jelezni kell a 'nem észlelhető - XH' és/vagy 'nem várható - XV' válaszok bekarikázásával. Az adatlap második oldalán gyüjtjük a tipikus fajok, özönfajok és a degradációt jelző, valamint az egyéb fajok előfordulását és dominancia viszonyait. Minden élőhelyre külön-külön összeállítottuk a tipikus és özön fajok végleges ellenőrző listáit. Ennek a két listának a jellegzetessége, hogy nem csak az elöfordulásukat (és dominancia kategóriájukat) kell rögzíteni, hanem a negatív, 'NINCS - nem fordul elö' eseteket is. Mindezeket a teljes MVT elég részletes bejárása alapján lehet megadni és áttekinteni, ezért a négy részminta bejárása és felmérése után célszerü az 1 ha-ra vonatkozó információkat véglegesíteni. A teljes (1 hektáros) mintavételi területről az M.2A adatlap és leírása szerinti felmérést végezzük el és dokumentáljuk (3. és 4. ábra). 
A részminták felmérésének áttekintése

Az 1 hektáros MVT-en belül 4 részfelmérést kell készíteni az erdőszerkezet, a vadhatás, a faállomány, a cserjeszint és a felújulóképesség jellemzésére. A részmintákat hozzávetőleg 1-1,5 famagasság (fahossznyi), de legfeljebb $25 \mathrm{~m}$ sugarú körökben mérjük fel. Ezekben megadjuk az Á-NÉR 2011 élőhelykategóriát (Bölöni et al. 2011), és becsüljük a szintezettséget, a lombkoronaszint (A) összes záródását (maximum 100\%), az újulati- és cserjeszint (B), az aljnövényzeti szint (C), valamint a mohaszint, liánszint, és erózió kiterjedése szerinti borításokat. Egy-egy részminta könnyen áttekinthetően, bejárhatóan kis területre vonatkozik, ezért a borítások becslése egyszerübb, mintha azt a teljes hektárra vonatkozóan tennénk. A felmérés és dokumentálás során a részminta területének körbejárása javasolt. Sürü cserjeszint vagy fiatalos esetén azonban ez sem túl egyszerü. A szintek jellemzésén kívül a faállomány-szerkezet és összetétel leírására fafajsorokat képezünk. A részmintákba kerülő összes fásszárú (fák és cserjék) fajról készítünk fafajsoros leírást. Fafajsornak tekintjük egy fásszárú fajnak a többitől határozottan elkülönülő méretosztályát előre megadott mellmagassági átmérő kategóriák (5-15 cm, 15-30 cm, 30-60 cm, >60 cm) szerint, amelyeket választható dominancia-kategóriákkal is jellemzünk (pl. az „A” lombkorona szintben a kocsánytalan tölgyeket: KTT 15-30 cm átmérőjü és 25-50\% dominanciájú; és egy KTT 5-15 $\mathrm{cm}, 1-5 \%$ dominanciájú fafajsorokkal). További fafajsorokat írunk le az újulatiés cserjeszintre (B), valamint az aljnövényzeti szintre (C) is, ahol viszont mellmagassági átmérőt már nem lehet/kell megadni. Ezekből az adatokból egyszerüen és elegendő pontossággal állapíthatók meg az elegyarány, átmérő- és korosztályviszonyok fó jellemzői, az uralkodó fafajok felújulási potenciálja, valamint könynyen képezhetők a természetes, inváziós, termőhelyidegen és egyéb ökológiai szempontból értelmezhető tulajdonságok, ill. a Natura 2000 (N2K) szerkezet és funkció szempontok szerinti indikátorváltozók nagy része (Szegleti et al. 2017). A részmintavételt az M.2B jelzésü adatlapokon dokumentáljuk. A részminta adatlap az 5. ábrán látható.

\section{A korcsoport eloszlások reprezentativitásának problémája}

Az erdős élőhelyek védelme és monitorozása az OEA szerint elsősorban a természetes, természetszerü és származék erdő természetességi fokozat besorolású erdőrészletekre irányul. Azonban a Natura 2000 szerkezet és funkció monitorozás 2008-ban tervezett mintavételi helyeinek korcsoport eloszlása ugyanezen kategóriákban nagyon eltér az országos korcsoport eloszlástól (6. ábra).

Az 1-20 és 21-50 éves korosztályok részaránya az OEA-ban 17,0\% és 26,4\%, míg a tervezett $\mathrm{N} 2 \mathrm{~K}$ mintában csak 4,9\% és 14,7\%. A fiatalabb korosztályokat 
M.2A

MVT név

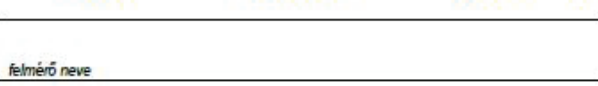

MNT ssz

ülố bükkösök

9110 mészker

Natura 2000 éбhely (ród és név)
$=$ ha, 1-10ha, >10ha, NEM ISM becsütt állományméret
FID: ...

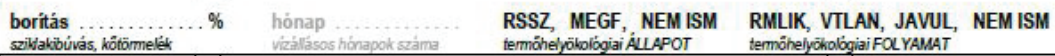

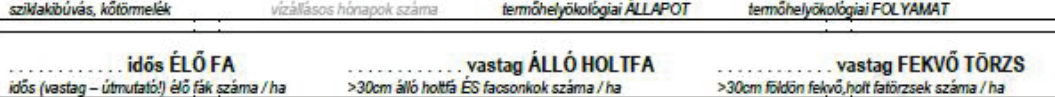

termkōzERDŌ, CSERJ, GYEP, VIZES, VÁGÁS leromlott ÉH, INVÁZIÓS FAŨLTETV, AGRÁR, TELEP NEM ISMERT
200m-es körzeten (kb. 12,5 ha) belïl találhate, szomszédos" éb̆helycsoportok felsorolása

\section{NEM ELSZIGETELT $\quad<200 \mathrm{~m}, 200-500 \mathrm{~m}, 500 \mathrm{~m}, 500-1000 \mathrm{~m}$, TÁVOLABBI}

lequózelebbi. azonas (vagy az élóhelysorozatha jól ileszkedô) écóhely távolsága

\begin{tabular}{|c|c|c|}
\hline $\begin{array}{l}\text { VÁ / ÁT / SZÁ / NEM } \\
\text { endészeti üzemmód }\end{array}$ & legutóbbi ( $k b .3$ éves idószak) erod̄használata & $\begin{array}{l}\text { VÉD / KŌZJ / GAZD } \\
\text { elsödleges rendeltetés }\end{array}$ \\
\hline
\end{tabular}

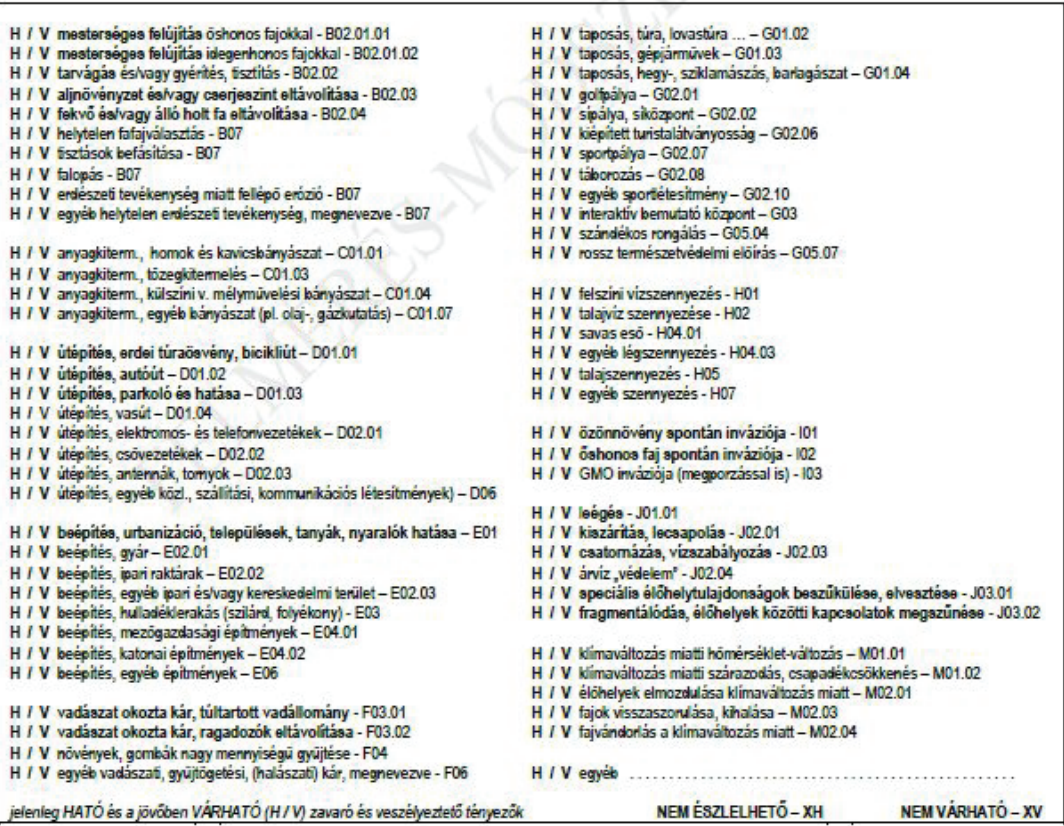

3. ábra. Az „M.2A” felmérö adatlap első oldala mészkerülő bükkösök (9110) esetére. Az adatlap és a kitöltési útmutató letölthető: a http://www.erdorezervatum.hu/N2KMON_modszertan honlapról. 
MTA

OKKOLOGIAI KUTATOKÖZPONT

\section{M.2A - tipikus fajok, özönfajok, degradációt jelző fajok}

Tipikus - kedvezỗ állapotokat indikáló - fajok elôfordulása, dominanciäja a (C) gyepszintben MÉSZKERÜLÖ BÜKKÖSÖK

\begin{tabular}{|c|c|}
\hline Avenella (Desch.) flexuosa & NINCS, van, $1-5 \%$, több \\
\hline Calamagrostis arundinacea & NINCS, van, $1-5 \%$, több \\
\hline Genista pilosa & NINCS, van, $1-5 \%$, több \\
\hline Hieracium spp. & NINCS, van, $1-5 \%$, több \\
\hline korpafüvek & NINCS, van, $1-5 \%$, több \\
\hline körtikék & NINCS, van, $1-5 \%$, több \\
\hline Leucobryum glaucum & NINCS, van, $1-5 \%$, \\
\hline Luzula luzuloides & NINCS, van, $1-5 \%$, több \\
\hline Melampyrum pratense & NINCS, van, $1-5 \%$, töl \\
\hline Prenanthes purpurea & NINCS, van, $1-5 \%$, \\
\hline
\end{tabular}

Vaccinium spp. NINCS, van, $1-5 \%$, több

Veronica officinalis NINCS, van, $1-5 \%$, több NINCS, van, $1-5 \%$, több NINCS, van, $1-5 \%$, több NINCS, van, $1-5 \%$, több NINCS, van, $1-5 \%$, több NINCS, van, $1-5 \%$, tōbb NINCS, van, $1-5 \%$, több NINCS, van, $1-5 \%$, több NINCS, van, $1-5 \%$, több

Özönfajok elôfordulása, dominanciảja a (C) gyepszintben

\begin{tabular}{|llllll|}
\hline Acer negundo & N V 1-5\% T & Fallopia spp. & N V 1-5\% T & Prunus serotina & N V 1-5\% T \\
Ailanthus altissima & N V 1-5\% T & Fraxinus pennsylv. & N V 1-5\% T & Robinia p.acacia & N V 1-5\% T \\
Amorpha fruticosa & N V 1-5\% T & Helianthus spp. & N V 1-5\% T & Solidago adv. & N V 1-5\% T \\
Asclepias syriaca & N V 1-5\% T & Heracleum adv. spp. N V 1-5\% T & Vitis spp. & N V 1-5\% T \\
Aster adv. spp. & N V 1-5\% T & Impatiens adv. spp. N V 1-5\% T & & N V 1-5\% T \\
Echinocystis lobata & N V 1-5\% T & Parthenocissus spp. N V 1-5\% T & & N V 1-5\% T \\
Enigeron annuus & N V 1-5\% T & Phytolacca spp. & N V 1-5\% T & & N V 1-5\% T \\
\hline
\end{tabular}

Degradációt jelzõ fajok a (C) gyepszintben - CSAK HA TÖMEGES (legalább 5\% vagy több)

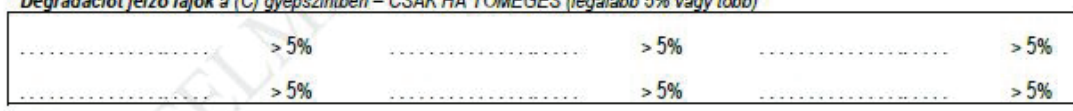

Egyéb fajok, megjegyzés

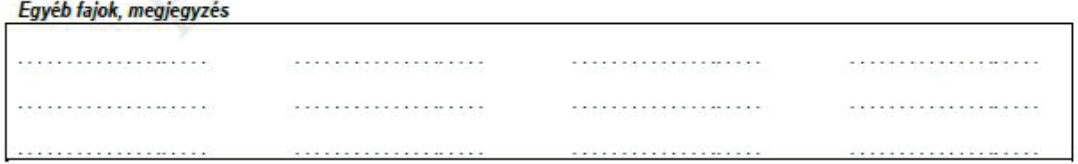

IGEN, NEM, NEM ISMERT Keritike a felúitiásokat?

Ellenôrzés: $\quad$ RM-1?
NEM, TÉLEN IGEN, NYÁRON IS, NEM ISMERT Eletike rendszeresen a nagyadat?

$R M-3$ ?
RM-4?

FOTÓK?

FAJOK?

4. ábra. Az „M.2A” felmérő adatlap második, tipikus fajok, özönfajok, degradációt jelző és egyéb fajok dokumentálását szolgáló oldala mészkerülő bükkösök (9110) esetére. Az adatlap és a kitöltési útmutató letölthető a http://www.erdorezervatum.hu/N2KMON_modszertan honlapról. 
M.2B-1 - részminta, MVT név. FID: ....

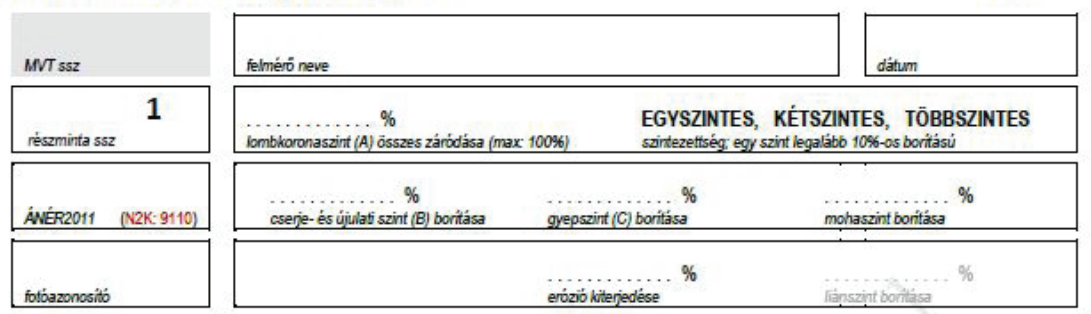

\begin{tabular}{|c|c|c|c|}
\hline $\begin{array}{l}\text { NINCS, KEVÉS, 50\%, 100\%, n.é } \\
\text { Ĺfjulat fatalos (A. B) hántottsága }\end{array}$ & $\underset{\text { NIN }}{\text { Nijulat }}$ & $\begin{array}{l}\text { ÉVÉS, } 50 \%, 100 \% \text {, n.é. } \\
\text { ágottsága, CSERJESZINT(B) }\end{array}$ & $\begin{array}{l}\text { NINCS, KEVÉS, } \sim 50 \%, 100 \% \text {, n.é. } \\
\text { újulat csúcsrágottsága: GYESZINT (C) }\end{array}$ \\
\hline $\begin{array}{l}\text { VDI TÚRÁS VADCSAPA } \\
\text { nagyad friss nyomok és élefielek }\end{array}$ & KIFEKVÉS & VDI HULLATÉK & EGYÉB HULLATÉK \\
\hline
\end{tabular}

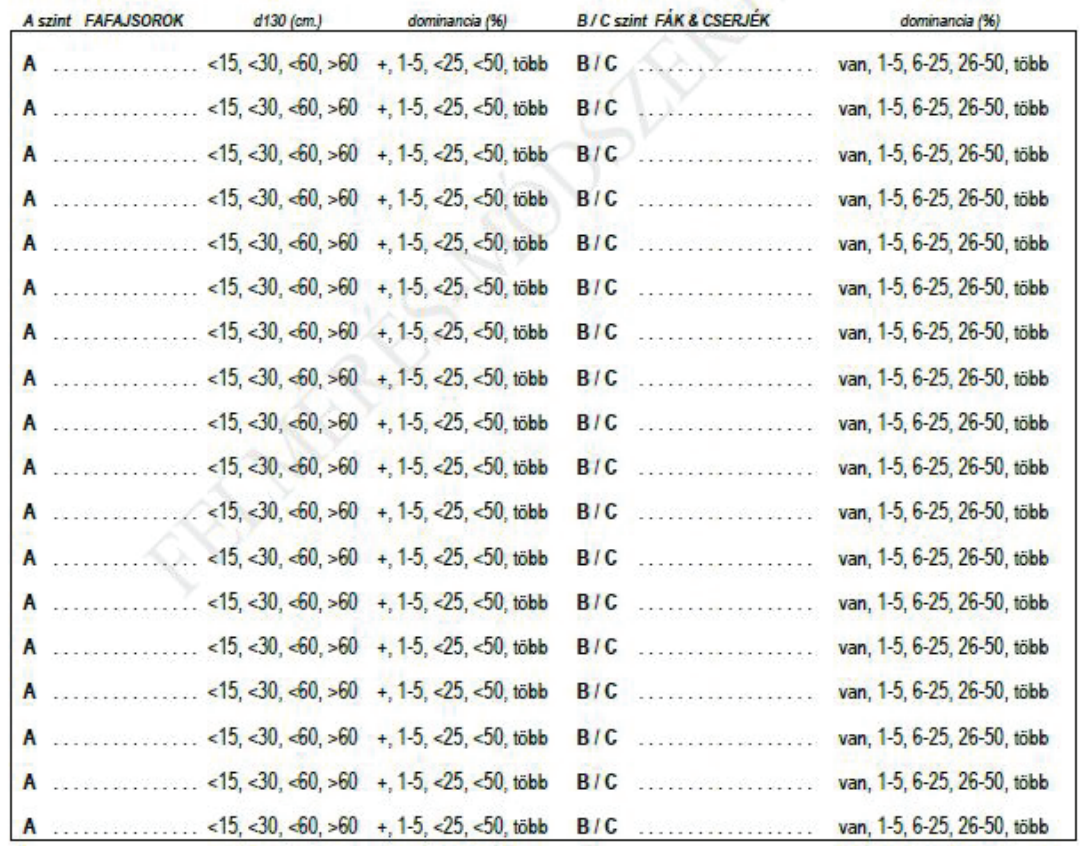

5. ábra. Az „M.2B” részminta felmérő (fafajsoros) adatlap mészkerülő bükkösök (9110) esetére. Az adatlap és a kitöltési útmutató letölthetö a http://www.erdorezervatum.hu/N2KMON_modszertan honlapról 
a tervezett N2K mintavétel alulreprezentálja. Ezzel szemben a 80 évesnél öregebb erdők korosztálya az OEA-ban 26,6\%, míg a terezett N2K mintában 47,1\%. Az 50 év feletti, különösen pedig a 80 évnél öregebb állományok tervezett N2K monitorozó mintavétele tehát túlreprezentált. Ennek néhány évtized után várható következménye az lesz, hogy a vágásos üzemmód következtében egyre nagyobb arányban kerülnek az öregebb erdőrészletek végvágásra, felújításra, majd fiatalabb korosztályba. Ez a hatás elsősorban a gazdasági rendeltetésü, nagy kiterjedésü, zonális, ill. nyereséges gazdálkodást biztosító állományoknál várható. Az erdők országos állapotáról a monitorozás eleinte kedvezőbb képet adna (az aránytalanul sok öreg erdő miatt), később viszont éppen ellenkezőleg, az átlagosnál kedvezőtlenebbet (a sok fiatalos miatt). Az országos mintavételi tervet tehát nem csak az erdőtípusok elterjedtségével arányosan, hanem a korosztályviszonyok kiegyensúlyozottabb képviseletének irányába szükséges bỏvíteni. A 2-es táblázat az erdei élőhelytípusok országosan becsült összes kiterjedését mutatja 2007-ben, 2013-ban és 2014-ben (KvVM 2008, VM 2014, Molnár 2014), továbbá a 2008-ban javasolt mintaszámokat (Horváth et al. 2008), valamint egy új,

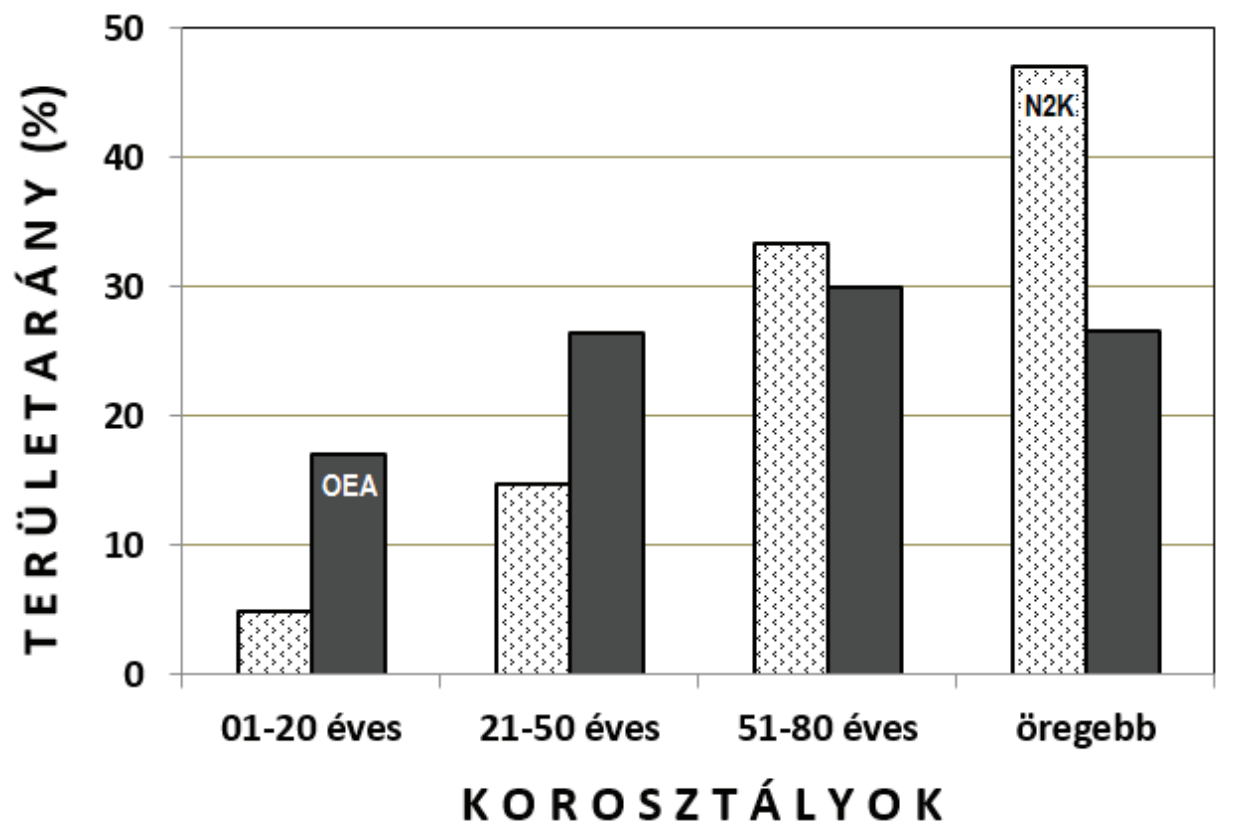

6. ábra. A természetes, természetszerü és származék besorolású erdők korosztály eloszlása az Országos Erdőállomány Adatbázis értékelése alapján (NÉBIH, 2011 december, 1.022.678 ha - OEA, sötét oszlopok) és a 2008-ban tervezett Natura 2000 erdős mintavételi helyek (1337 értékelhető mintavételi hely - N2K, világos oszlopok) korosztály viszonyai. A két korosztály eloszlás nagyon eltér egymástól. Az N2K tervben a fiatalabb erdők alul-, az idősebb erdők túlreprezentáltak. 
kibővített javaslatot, amely lehetővé teszi a vágásos erdőgazdálkodásból fakadó alulreprezentált fiatalabb korosztályok kiegyenlítését (2. táblázat). A korosztályok reprezentáltsága a mintavétel során elsősorban gazdasági erdőknél fontos, ezért a zonális bükkösök, gyertyános-tölgyesek és cseres-tölgyesek (9130, 91G0, 91 K0, 91L0, 91M0), valamint a keményfás és puhafás ligeterdők (91F0, 91E0) körében szükséges (és lehetséges) a mintavétel bővítése. A korábban tervezett 1751 minta helyett 1935 és 2406 MVT közötti becslést adtunk, amely a korábbi átlagos négyzetkilométerenkénti 0,32 minta helyett 0,35-0,44 MVT / $\mathrm{km}^{2}$ mintavételi intenzitást jelentene. A többi, sokkal kisebb összkiterjedésủ élőhely $(9110,9150,9180$, 91H0, 91I0, 91N0) nagy része védett, ill. véderdő ahol az öregebb erdőállományok részaránya magasabb. Ezekben a korosztályos reprezentativitás problémája nem olyan jelentős, mert nagy részben természetvédelmi korlátozás alá esnek, amelyeket kivontak a gazdálkodás alól (az erdőgazdálkodás eleve gazdaságtalan) vagy kíméletesebb módon kezelendők.

\section{Értékelés és kitekintés}

Az európai konzervációbiológiai publikációk között viszonylag kevés van, amely a Natura 2000 erdei élőhelyek monitorozásának módszertani kérdéseivel foglalkozik. Cantarello \& Newton (2008) egy-egy terepi mintaterület alapú, mintaponttranszekt menti és szakértői vizuális felmérésen alapuló kvantitatív indikátoros értékelési módszert vet össze angliai és olaszországi mintaterületeken. Hernando et al. (2010) és Velázquez et al. (2010) térinformatika rendszerbe ágyazottan, távérzékelt felvételek felhasználásával, néhány mediterrán élőhelytípusra (ezek közül kettő tekinthetô erdeinek) olyan lehatárolási módszert alkalmazott, amelynél elsődleges az élőhelytípus állományainak térképezése, miközben ezt a várható, ill. tervezett területhasználattal és élőhelykezeléssel is összhangba hozza. A kezelésekkel és az állományok sérülékenységével együtt, környezeti diagnózisba integrálja a monitorozás eredményét. Négy szempontra használ kategória indikátorokat: i) az állomány funkcionális egészsége 3 fokozatban, a természetes folyamatok teljessége alapján; ii) regenerációs képesség; iii) egyszerủ fajgazdagsági kategorizálás tipikus fajok előfordulása alapján; iv) durva erdőszerkezeti kategóriák 3 fokozatban. Szlovéniában az erdőgazdálkodás meglévő információs rendszerét és az ún. ICP Forests projekt (International Co-operative Programme on Assessment and Monitoring of Air Polluton Effects on Forests) monitorozó rendszerét kiegészítve értékelik az N2K erdei élőhelytípusok természetvédelmi állapotát (Kutnar et al. 2011). Olaszországban Angelini et al. (2016) a közép-európai cönológiai módszer alkalmazására, ill. adaptálására tesz javaslatot. Látható, hogy nagyon széleskörü a módszertani megközelítés a terepi mintavételes felméréstől, 
2. táblázat. Magyarország Natura 2000 erdei élőhelytípusainak becsült országos kiterjedése az országjelentések (1 - KvVM (2008), 4 - VM 2014) és 5 - Molnár (2014) alapján, valamint a monitorozásra javasolt országos mintaszám 2008-ban (2 - Horváth et al. 2008) és a szerzők által javasolt új mintaszám (6). A javaslatokhoz tartozó mintavételi intenzitást a 3-as és 7-es oszlopok mutatják (további magyarázatot lásd a szövegben).

\begin{tabular}{|c|c|c|c|c|c|c|c|}
\hline $\begin{array}{l}\text { Natura } 2000 \text { erdei } \\
\text { élőhelyek kódja } \\
\text { és rövid magyar } \\
\text { elnevezése }\end{array}$ & $\begin{array}{c}1 . \\
\text { kiter- } \\
\text { jedés, } \\
\text { 2007-es } \\
\text { ország- } \\
\text { jelentés } \\
\left(\mathrm{km}^{2}\right)\end{array}$ & $\begin{array}{c}2 . \\
\text { javasolt } \\
\text { minta- } \\
\text { szám, } \\
2008 \\
\text { (db) }\end{array}$ & $\begin{array}{c}3 . \\
\text { minta- } \\
\text { vételi } \\
\text { sürüség, } \\
2008 \\
\left(\mathrm{db} / \mathrm{km}^{2}\right)\end{array}$ & $\begin{array}{c}4 . \\
\text { kiterjedés, } \\
2013 \text {-as } \\
\text { ország- } \\
\text { jelentés } \\
\left(\mathrm{km}^{2}\right)\end{array}$ & $\begin{array}{c}5 . \\
\text { becsült kiter- } \\
\text { jedés, } 2014 \\
\left(\mathrm{~km}^{2}\right)\end{array}$ & $\begin{array}{c}6 . \\
\text { új, } \\
\text { javasolt } \\
\text { minta- } \\
\text { szám, } \\
2017 \\
\text { (MVT) }\end{array}$ & $\begin{array}{l}7 . \\
\text { új mintavé- } \\
\text { teli sürüség, } \\
2017\end{array}$ \\
\hline $\begin{array}{l}9110 \text { Mészkerülő } \\
\text { bükkösök }\end{array}$ & 25 & 40 & 1,60 & 11 & $\begin{array}{l}<13 \text { nagy } \\
\text { része véderdő }\end{array}$ & 40 & 3,08 \\
\hline $\begin{array}{l}9130 \text { Szubmontán } \\
\text { és montán bük- } \\
\text { kösök }\end{array}$ & 740 & 130 & 0,18 & 750 & $\begin{array}{l}\text { kb. } 800 \text { gaz- } \\
\text { dasági erdők }\end{array}$ & $\begin{array}{c}169- \\
195\end{array}$ & $0,21-0,24$ \\
\hline $\begin{array}{l}9150 \text { Sziklai } \\
\text { bükkösök, sziklai } \\
\text { hárserdők }\end{array}$ & 15 & 85 & 5,67 & 23 & $\begin{array}{l}5-6 \text { nagy } \\
\text { része véderdő }\end{array}$ & $40-85$ & $7,27-15,45$ \\
\hline $\begin{array}{l}\text { 9180* Törmeléklej- } \\
\text { tő- és szurdokerdők }\end{array}$ & 37 & 100 & 2,7 & 40 & $\begin{array}{l}22 \text { nagy része } \\
\text { véderdő }\end{array}$ & $50-100$ & $2,27-4,55$ \\
\hline $\begin{array}{l}91 \mathrm{E} 0 * \text { Puhafás } \\
\text { ligeterdők, éger- és } \\
\text { kőrisligetek }\end{array}$ & 400 & 365 & 0,91 & 480 & $\begin{array}{l}450 \text { nagy ré- } \\
\text { sze gazdasági } \\
\text { erdő }\end{array}$ & $\begin{array}{c}475- \\
548\end{array}$ & $1,05-1,22$ \\
\hline $\begin{array}{l}\text { 91F0 Keményfás } \\
\text { ligeterdők }\end{array}$ & 300 & 180 & 0,60 & 350 & $\begin{array}{l}\text { 200-250 nagy } \\
\text { része gazdasá- } \\
\text { gi erdő }\end{array}$ & $\begin{array}{c}234- \\
270\end{array}$ & $1,04-1,20$ \\
\hline $\begin{array}{l}\text { 91G0* Pannon } \\
\text { gyertyános-töl- } \\
\text { gyesek }\end{array}$ & 1350 & 180 & 0,13 & 900 & $\begin{array}{l}1500 \text { gazdasá- } \\
\text { gi erdők }\end{array}$ & $\begin{array}{c}234 \\
270\end{array}$ & $0,16-0,18$ \\
\hline $\begin{array}{l}\text { 91H0* Pannon } \\
\text { molyhos tölgyesek }\end{array}$ & 300 & 189 & 0,63 & 300 & $\begin{array}{l}230 \text { nagy ré- } \\
\text { sze véderdő }\end{array}$ & $\begin{array}{c}189- \\
246\end{array}$ & $0,82-1,07$ \\
\hline $\begin{array}{l}91 \mathrm{I} 0 * \text { Euro-szibé- } \\
\text { riai erdőssztyepp- } \\
\text { tölgyesek }\end{array}$ & 35 & 100 & 2,86 & 45 & $\begin{array}{l}35-50 \text { nagy } \\
\text { része védett }\end{array}$ & 100 & 2,35 \\
\hline 91K0 Illír bükkösök & 280 & 48 & 0,17 & 270 & $\begin{array}{l}200 \text { gazdasági } \\
\text { erdők }\end{array}$ & $62-72$ & $0,31-0,36$ \\
\hline $\begin{array}{l}\text { 91L0 Illír gyertyá- } \\
\text { nos-tölgyesek }\end{array}$ & 780 & 52 & 0,07 & 500 & $\begin{array}{l}600 \text { gazdasági } \\
\text { erdők }\end{array}$ & $68-78$ & $0,11-0,13$ \\
\hline $\begin{array}{l}\text { 91M0 Pannon } \\
\text { cseres-tölgyesek }\end{array}$ & 1500 & 242 & 0,16 & 1400 & $\begin{array}{l}1350 \text { gazdasá- } \\
\text { gi erdők }\end{array}$ & $\begin{array}{c}234 \\
288\end{array}$ & $0,17-0,27$ \\
\hline $\begin{array}{l}91 \mathrm{~N} 0 * \text { Pannon } \\
\text { homoki borókás- } \\
\text { nyárasok }\end{array}$ & 16 & 40 & 2,50 & 76 & $\begin{array}{l}13 \text { védett } \\
\text { erdők }\end{array}$ & 40 & 3,08 \\
\hline ÖSSZESÍTÉS: & 5778 & 1751 & 0,32 & 5145 & 5451 & $\begin{array}{c}1935- \\
2406\end{array}$ & $0,35-0,44$ \\
\hline
\end{tabular}


a korábbi erdőmonitorozó rendszerek és a cönológiai mintavételezés adaptálásán keresztül a térinformatikába és távérzékeléssel integrált monitorozáson keresztül az erdőgazdálkodásba, tájgazdálkodásba integrált megközelítésig. Az élőhelyek természetvédelmi monitorozása csak olyan lehet, amely új, terepi információt is tud szolgáltatni fajok előfordulása (biodiverzitási), valamint erdőszerkezeti és ökoszisztéma müködési indikátorok alapján.

A TERMERD projekt erdőtermészetesség felmérési és értékelési koncepciója (Bartha et al. 1998, 2003, 2006, 2007) megfelelő alapozást biztosított ahhoz, hogy azt a Natura 2000 monitorozás követelményeihez adaptálni lehessen. Ezt Bölöni (2008) korábban javasolt változata nagyrészt megvalósította, azonban a természetvédelmi szempontokat és az élőhelyvédelmi irányelv érvényesítését, valamint az országjelentések összeállítását jobban támogató, egyszerübb és hatékonyabb monitorozás kialakítását, fejlesztését a természetvédelem munkatársai és a program résztvevői kiemelten fontosnak tartották. A legfőbb fejlesztések, amelyekkel ezeket el tudtuk érni:

- $\quad$ az egységes, torzítatlan adatokat eredményező mintavétel (minden esetben 1 hektár és 4 részminta);

- a részminták középpontjainak bemérése és terepi jelölése, amely az újrafelméréskor gyorsabb és pontosabb visszatalálást eredményez;

- a faállomány-szerkezet fafajsoros leírásával egyértelmübb, objektívebb adatokhoz jutunk, egyszerübb a felmérés;

- továbbfejlesztettük az adatlapokon előre meghatározott kategória, ill. intervallum listákat (mint pl. a fajok előfordulásának, ill. dominanciájának jellemzésére a „nincs, van, 1-5\%, több” kategória változók), amelyek nagymértékben segítik a terepi felmérés egyértelmüségét, objektivitását és minőségét;

- elöre meghatározott és az adatlapokon tételesen felsorolt indikátor fajok (tipikus és özönfajok) előfordulását vagy hiányát kötelezően kell dokumentálni (megtanulásuk, felismerésük és célirányos megtalálásuk így viszont könynyebb; többen vehetnek részt a monitorozásban); ugyanakkor az egyéb fajok (akár a teljes fajkészlet) felsorolása is lehetséges;

- $\quad$ egy szakértői csoport segítségével erdei élőhelytípusonként kialakítottuk a tipikus fajok konszenzusos listáit (külön publikáljuk);

- elhagytuk a bizonytalan, szubjektív vagy alacsony indikációs értékkel rendelkező információk felmérését;

- aktualizáltuk, pontosítottuk és adaptáltuk az országjelentéshez közvetlenül felhasználható veszélyeztető tényezők listáját;

- $\quad$ struktúráltabb és élőhelytípusokra szabott adatlapokat alakítottunk ki, amely megkönnyíti a felmérést, majd az adatok feldolgozását;

- a felmérési eredmények értékelésére egy megalapozottabb és részletesebb módszertant dolgoztunk ki (lásd Szegleti et al. 2017). 
Az erdőrészletek szerint tagolt és ütemezett, döntően vágásos rendszerü erdőgazdálkodás a hazai tájban általában olyan mintázatot alakított ki, amelyben az egyes korosztályok (és a termőhely mintázatától függően az élőhelytípusok) állományai mozaikosan, kis távolságokon belül vegyesen fordulnak elő. Erre mutat példát a 7. ábra, ahol 500-1000 m sugarú körzeten belül 3-4 (általunk vizsgált) korosztálycsoport (1-21, 21-50, 51-80 éves valamint annál öregebb) állományai egymás melletti közvetlen szomszédságban találhatók. A monitorozás szűk keresztmetszete elsősorban az egyes mintavételi területek felkeresésére fordítandó idő és költség, általánosabb értelemben az ,utazási, kiszállási költség”, amely elsősorban a mintaszám, másodsorban pedig az egymástól vett „utazási távolság”ok függvénye.

A korosztályok helyes mintavételes képviselete érdekében több erdei élőhelytípusnál magasabb mintaszám szükséges, amelyre a 2. táblázatban teszünk javaslatot: összességében 1751 helyett minimálisan 1935 és legfeljebb 2406 közötti MVT-re, ez mintegy 10-37\% területszám bővítést jelent. A terepi felméréshez szükséges időt a továbbfejlesztett módszertan önmagában nem tudja jelentősen rövidíteni, azonban a MVT-ek kisebb csoportokba való részleges átszervezése a korosztályok és az élőhelytípusok mozaikos táji mintázatában nagymértékben csökkentheti a monitorozás költségét a nélkül, hogy az csökkentené az országos reprezentativitás objektivitását. Kisebb területi csoportoknál egy felmérő napi 4-5 MVT felmérésére képes, míg a rétegzett random kijelölésen alapuló monitorozás során az idő nagy részét az utazás teszi ki, napi 1-2, legfeljebb 3 MVT teljesítménnyel. A monitorozási területek kijelölésének és szervezésének országos, vagy regionális szintje akkor biztosítja a leginkább költséghatékony eredményt, ha a 2008-as terv még meg nem valósított részét az adott tájegységen belül, de a már korábban kitüzött, felmért pontok közelébe, vagy új csoportokba szervezi, figyelembe véve a természetközeli erdőterületek országos korosztály szerkezetét is. Az adatok bevitele, ellenőrzése és feldolgozása nem elhanyagolható mértékü erőforrást igényel, amivel a korábbi módszertan nem számolt. Egy mintavételi terület létesítése és adatainak rögzítése külön munkafolyamat, amelyet persze csak első alkalommal kell elvégezni. Külön munkafolyamat a felmért adatok feldolgozása, amely tapasztalataink szerint átlagosan 30-50 percet igényel. Sok fafajsort és faj előfordulását tartalmazó adatlap feldolgozása hosszabb ideig tart, hiányos vagy hibás információ esetén utólagos kiegészítésre is szükség lehet.

A továbbfejlesztett Natura 2000 szerkezet és funkció módszertannal a monitorozók már 2014-tôl dolgoznak. A Svájci-Magyar Együttmüködési Program (SH/4/8) keretében 2016 végéig, a 2008-as terv kijelöléseitől függetlenül további 500 mintavételi pontot meghaladó MVT-t mértünk fel. Időközben elkészítettük a monitorozás központi adatbázisát, adatfeldolgozó programját és 


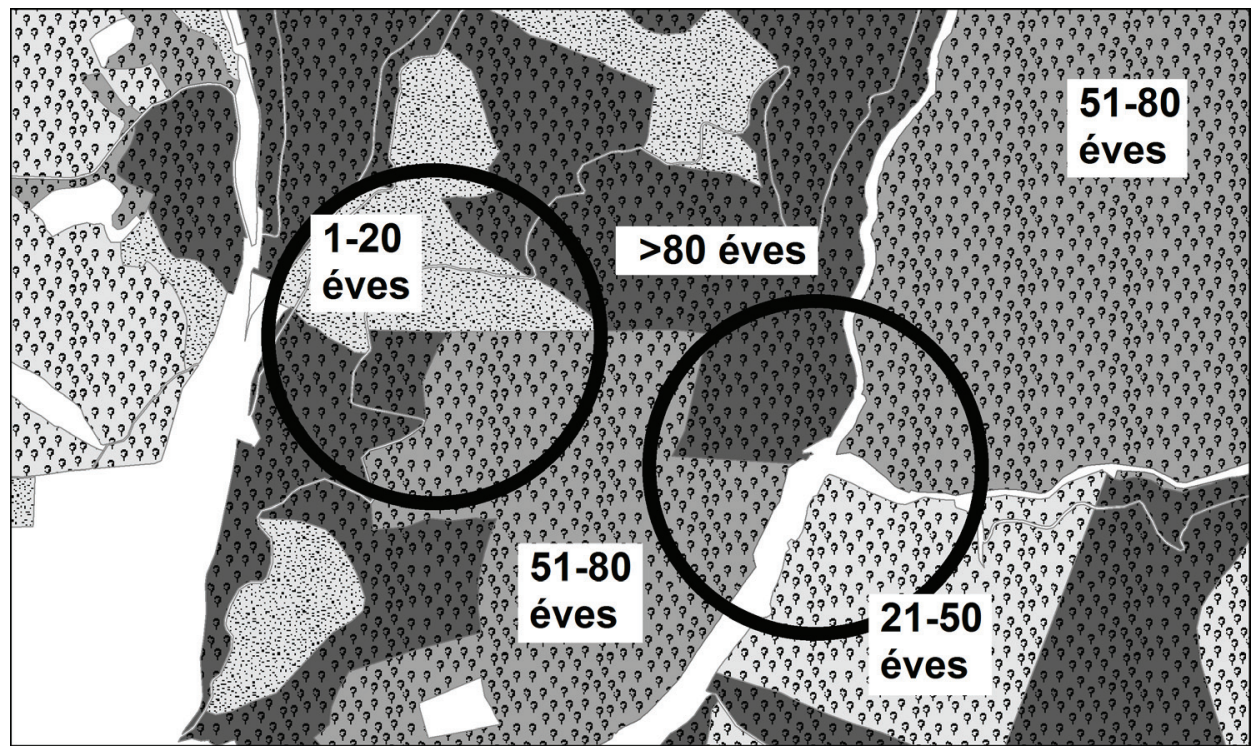

7. ábra. Példa a vágásos üzemmódban kezelt erdők állományainak jellemző, táji korosztály-mintázatára. A képen ábrázolt 500 m sugarú körökön belül természetközeli állományok 3-3 korosztálya található. A bal oldali példán 1-20 éves fiatalos, 51-80 éves középkorú és 80 évnél öregebb, míg a másikon 21-50 éves, 51-80 éves és öreg erdő.

honlapját (www.erdovigyazo.hu), amely támogatja a módszertan és felméréshez fontos fajok önálló megtanulását, a felmérés alkalmazását és az alapadatok feldolgozását. Az eredmények egységes értelmezése és további hatékony felhasználása érdekében kidolgoztuk az értékelés módszerét, amely a TERMERD projekt erdőtermészetességi koncepció adaptációján alapszik (Szegleti et al. 2017).

A felkért szakértői csoport által konszenzussal összeállított tipikus fajok listái az adatlapokon megtalálhatók. Ezek publikálása és a konszenzusra jutó folyamat és a listák indoklása még folyamatban van. Dolgozunk továbbá a Szegleti et al. (2017) által publikált értékelési módszertan informatikai megvalósításán.

Az elkészült rendszer és a még fejlesztés alatt álló értékelés megvalósítása alapadatokkal és részletes összesítésekkel tudja segíteni a monitorozás és az országértékelés munkáját, de az abban végzendő szakértői munkát nem helyettesíti. Fontos és aktuális, de nem kizárólagos információ forrást képes nyújtani az erdei élőhelytípusok természetvédelmi állapotának elemzéséhez és értékeléséhez. Minél inkább képesek vagyunk a tervezett mintaszámot elérni és fenntartani (vagy akár meghaladni), annál megbízhatóbb és világosabb képünk lesz erdeink állapotáról, amely alapján a természetvédelem döntéstámogató és közérdek érvényesítő szakpolitikai ereje jelentősen javulhat. 
Köszönetnyilvánitás - A Natura 2000 szerkezet és funkció monitorozás továbbfejlesztett módszerének kidolgozását a Svájci-Magyar Együttműködési Program finanszírozta „A fenntartható természetvédelem megalapozása magyarországi Natura 2000 területeken" elnevezésű, SH/4/8 jelü projekt keretében. Köszönetet mondunk a módszer továbbfejlesztésében, megvitatásában, kipróbálásában és tesztelésében aktívan közreműködő természetvédőknek, erdészeknek és ökológus kutatóknak, továbbá e kézirat két, névtelenségben is gondos kritikusának, lektorának.

\section{Irodalomjegyzék}

Angelini, P., Casella, L., Grignetti, A. \& Genovesi, P. (eds.) (2016): Manuali per il monitoraggio di specie e habitat di interesse comunitario (Direttiva 92/43/CEE) in Italia: habitat. - ISPRA, Serie Manuali e linee guida, $142 \mathrm{p}$.

Bartha, D. (2005): A magyarországi erdők természetességének vizsgálata. - MTA Doktori Értekezés, Sopron, 186 p. Forrás: http://real-d.mtak.hu/314/

Bartha, D., Bölöni, J., Ódor, P., Standovár, T., Szmorad, F. \& Tímár G. (2003): A magyarországi erdők természetességének vizsgálata. - Erdészeti Lapok 138: 73-75.

Bartha, D., Gálhidy, L. (szerk.), Aszalós, R., Bartha, D., Bodonczi, L., Bölöni, J., Kenderes, K., Ódor, P., Standovár, T., Szmorad, F. \& Tímár, G. (2007): A magyarországi erdők természetessége. - WWF Füzetek 27., WWF Magyarország, 44 p.

Bartha, D., Ódor, P., Horváth, T., Tímár, G., Kenderes, K., Standovár, T., Bölöni, J., Szmorad, F., Bodonczi, L. \& Aszalós, R. (2006): Relationship of tree stand heterogeneity and forest naturalness. - Acta Silv. Lign. Hung. 2: 7-22.

Bartha, D., Szmorad F. \& Tímár G. (1998): A magyarországi erdők természetességének erdőrészlet szintü értékelési lehetősége. - Erdészeti Lapok 133: 74-77.

Bölöni, J. (2008): Natura 2000 monitorozási adatlap: erdők extenzív felmérése; Kitöltési útmutató; Kiértékelési útmutató - In: Horváth, A., Bartha, S., \& Bölöni, J. (szek.): A Natura 2000 élőhely monitorozó protokollok kidolgozása és tesztelése. Struktúra és funkció protokoll. - Kutatási jelentés a „Madárvédelmi (79/409/EGK) és az élőhelyvédelmi (92/43/EGK) irányelveknek megfelelő monitorozás előkészítése (2006/018-176.02.01 számú Átmeneti Támogatás projekt)" keretében. MTA Ökológiai és Botanikai Kutatóintézete, Vácrátót, pp. 101-103, 127-139.

Bölöni, J., Molnár, Zs. \& Kun, A. (szerk.) (2011): Magyarország élőhelyei. A hazai vegetációtípusok leírása és határozója. ÁNÉR 2011. - MTA Ökológiai és Botanikai Kutatóintézete, Vácrátót, $441 \mathrm{p}$.

Cantarello, E. \& Newton, A. C. (2008): Identifying cost-effective indicators to assess the conservation status of forested habitats in Natura 2000 sites. - Forest Ecol. Manag. 256: 815-826. doi: http://dx.doi.org/10.1016/j.foreco.2008.05.031

EC ENV: European Commission, Environment, Habitat Directive reporting, web page. - URL: http://ec.europa.eu/environment/nature/knowledge/rep_habitats/index_en.htm, utoljára letöltve: 2017 május 10-én

EEA EIONET: European Environmental Agency, EIONET, Reference portal for Natura 2000. Reference list 12. Threats, Pressures, Activities (final version, fájl: Ref_threats_pressures_FINAL_20110330.xls) - URL: http://bd.eionet.europa.eu/activities/Natura_2000/reference portal, utoljára letöltve: 2013 április 8-án

VM (2014): Hungarian report on the main results of the surveillance under article 17 for annex I habitat types (Annex D), Vidékfejlesztési Minisztérium, Forrás: EIONET, Biodiversity, Article 
17, Habitat report, Habitat assessments at Member State level - URL: http://bd.eionet.europa. eu/article17/reports2012/habitat/report/?period=3\&group=Forests\&country=HU\&region=PAN, lekérdezés: 2017 május 10-én

KvVM (2008): Delivery of the repors on the article 17. of the Habitats Directive, HUNGARY, 04 Mar 2008, Környezetvédelmi és Vidékfejlesztési Minisztérium, Forrás: EIONET CDR - European Information and Observation Network, Central Data Repository web portal, Hungary, completed envelope - URL: http://cdr.eionet.europa.eu/hu/eu/art17/envre7qhw/overview, lekérdezés: 2017 május 10-én

Evans, D. \& Arvela, M. (2012): Assessment and reporting under Article 17 of the Habitats Directive Explanatory Notes \& Guidelines for the period 2007-2012. - European Topic Center on Biological Diversity, Habitats Committee, Paris. - URL: http://circa.europa.eu/Public/irc/env/monnat/ library?1=/expert_reporting/work-package_revision/consultation_committee_1/guidelines habcompdf/EN $1.0 \& \mathrm{a}=\mathrm{d}$

Hernando, A., Tejera, R., Velázquez, J. \& Núñez, M. V. (2010): Quantitatively defining the conservation status of Natura 2000 forest habitats and improving management options for enhancing biodiversity. - Biodivers. Conserv. 19: 2221-2233. doi: http://dx.doi.org/10.1007/s10531-010$\underline{9835-8}$

Horváth, A., Bartha S. \& Bölöni J. (2008): A Natura 2000 élőhely monitorozó protokollok kidolgozása és tesztelése. Struktúra és funkció protokoll. - Kutatási jelentés a „Madárvédelmi (79/409/ EGK) és az élőhelyvédelmi (92/43/EGK) irányelveknek megfelelő monitorozás előkészítése (2006/018-176.02.01 számú Átmeneti Támogatás projekt)” keretében. MTA Ökológiai és Botanikai Kutatóintézete, Vácrátót, 159 p.

Horváth F. (2011): Az újulati és cserjeszint felmérésének ajánlott módszere az ERDÖ+h+á+l+ó mintavételi pontjaiban (MVP ÚJCS). - Kézirat, MTA ÖK ÖBI, Vácrátót, ER Archivum (2011/D004)

Horváth F., Gergely Z., Mázsa K., Bidló A., Kovács G., Bölöni J., Mányok G., Jelitai E. \& Ódor P. (2011): A faállomány-szerkezet felmérésének ajánlott módszere az ERDÖ+h+á+l+ó mintavételi pontjaiban (MVP FAÁSZ). - Kézirat, MTA ÖK ÖBI, Vácrátót, ER Archivum (2012/D)

Horváth, F. (2012). Módszertani fejlesztések az erdörezervátumok hosszú távú faállomány-szerkezeti kutatásához. - Nyugat-Magyarországi Egyetem. Roth Gyula Erdészeti és Vadgazdálkodási Tudományok Doktori Iskola, Doktori $(\mathrm{PhD})$ értekezés

Kutnar, L., Matijašić, D., \& Pisek, R. (2011): Conservation status and potential threats to natura 2000 forest habitats in slovenia. - Sumar. List 135: 215-231.

Louette, G., Adriaens, D., Paelinckx, D. \& Hoffmann, M. (2015): Implementing the Habitats Directive: How science can support decision making. - J. Nat. Conserv. 23: 27-34.

Molnár, Zs. (szerk.) (2014): Élőhelyek. - In: Haraszthy, L. (szerk.): Natura 2000 fajok és élőhelyek Magyarországon. - Pro Vértes Közalapítvány, Csákvár. 934 p.

Molnár, Zs., Bartha, S., Seregélyes, T., Illyés, E., Tímár, G., Horváth, F., Révész, A., Kun, A., Botta-Dukát, Z., Bölöni, J., Biró, M., Bodonczi, L., Deák, J. Á., Fogarasi, P., Horváth, A., Isépy, I., Karas, L., Kecskés, F., Molnár, Cs., Ortmann-né Ajkai, A. \& Rév Sz. (2007): A grid-based, satellite-image supported, multi-attributed vegetation mapping method (MÉTA). - Folia Geobot. 42: $225-247$.

Németh, F., Seregélyes, T. (1989): Természetvédelmi információs rendszer: Adatlap kitöltési útmutató. - Környezetgazdálkodási Intézet, Budapest, 46 p.

Ódor, P., Bölöni J. \& Standovár T. (2009): Felvételezési protokoll az aljnövényzet mintavételére az erdőrezervátum hosszú távú vizsgálatsorozat (HTV) keretében. - Kézirat, ER Archívum (2009/ D-008/1-2) 
Salafsky, N., Salzer, D., Stattersfield, A. J., Hilton-Taylor, C., Neugarten, R., Butchart, S. H. M., Collen, B., Cox, N., Master, L. L., O'Connor, S., Wilkie, D. (2008). A standard lexicon for biodiversity conservation: unified classifications of threats and actions. - Cons. Biol. 22: 897-911. doi: http://dx.doi.org/10.1111/j.1523-1739.2008.00937.x

Szegleti, Zs., Csicsek, G., Szabó, G., Zimmermann, Z., Bölöni, J. \& Horváth, F. (2017): Erdőtermészetesség szempontú értékelési módszer a Pannon életföldrajzi régió Natura 2000 erdőtípusainak szerkezet és funkció monitorozása alapján. - Természetvédelmi Közlem. 23: 100117. doi: http://dx.doi.org/10.20332/tvk-jnatconserv.2017.23.100

Tejera, R., Núñez, M. V., Hernando, A., Velázquez, J. \& Pérez-Palomino, A. (2012): Biodiversity and Conservation Status of a Beech (Fagus sylvatica) Habitat at the Southern Edge of Species' Distribution. - In: A. G. Lameed (ed.) Biodiversity Enrichment in a Diverse World. InTech, Rijeka, pp. 63-84.

Velázquez, J., Tejera, R., Hernando, A. \& Núñez, M. V. (2010): Environmental diagnosis: Integrating biodiversity conservation in management of Natura 2000 forest spaces. - J. Nat. Conserv. 18: 309-317. doi: http://dx.doi.org/10.1016/j.jnc.2010.01.004

\section{Internetes hivatkozások:}

http1: http://www.erdorezervatum.hu/N2KMON_modszertan

http2: http://www.erdovigyazo.hu 


\title{
Method for monitoring of structure and function's of Natura 2000 forest habitats in the Pannonian biogeographical region
}

\author{
Ferenc Horváth ${ }^{1}$, Csaba Molnár ${ }^{2}$, Adrienne Ortmann-né Ajkai ${ }^{3}$, \\ Gábor Csicsek ${ }^{4}$, Gábor Szabó ${ }^{1}$, Zita Zimmermann ${ }^{1}$, Márió Lukács ${ }^{1}$ \\ and Bölöni János ${ }^{1}$ \\ ${ }^{1}$ MTA Centre for Ecological Research, Institute of Ecology and Botany, \\ H-2163 Vácrátót, Alkotmány u. 2-4, Hungary \\ ${ }^{2}$ H-3728 Gömörszölös, Kassai u. 34, Hungary \\ ${ }^{3}$ University of Pécs, Department of Ecology and Hidrobiology, \\ H-7624 Pécs, Ifjúság útja 6, Hungary \\ ${ }^{4}$ University of Pécs, Doctoral School of Biology, \\ H-7624 Pécs, Ifjúság útja 6, Hungary \\ e-mail: horvath.ferenc@okologia.mta.hu
}

The Habitat Directive is devoted to ensure maintaining and improving the favourable conservation status of natural habitats remained. Monitoring of Natura 2000 habitats is necessary for that very reason. We are developed a simplified and more efficient way of structure and function monitoring of forest habitats for the Pannonian biogeographical region than the previous version proposed in 2008. The main goal is to reach a higher sampling effort to get to a statistically robust representativity. We harmonized it with the methods of the long term research program of Strict Forest Reserves of Hungary for that results can be served as real benchmarks. This renewed method is applied from 2014 by the nature conservation for monitoring of natural, semi natural or transformed forests of Hungary in excess of 1 million hectars. We present here the method, the field survey process and data froms in detail.

Keywords: Habitat Directive, forest naturalness, nature conservation monitoring, favourable conservation status, country report, TERMERD project 